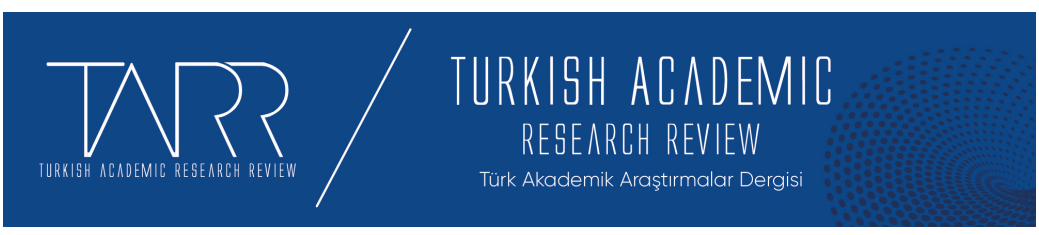

e-ISSN: 2602-2923 Yil/Year: $2021 \quad$ Cilt/Volume: 6 Sayı/Issue: 3

\title{
Cinuçen Tanrıkorur’un İlâhî Formundaki Bestelerinin Biçim Yönünden Tahlîli
}

The Formal Analysis of Cinuçen Tanrıorur's Compositions in Hymnal Form

\section{Çağlar TOPTAŞ}

Öğr. Gör., Ankara Yıldırım Beyazıt Üniversitesi Türk Mûsikîsi Devlet Konservatuvarı, Türk Müziği Bölümü/Ankara Yıldırım Beyazıt University, Turkish Music State Conservatory, caglartoptas@hotmail.com, Orcid ID: 0000-0001-97449311

\begin{tabular}{r|l} 
Makale Bilgisi & Article Information \\
Makale Türü - Article Type & Araştırma Makalesi / Research Article \\
Geliş Tarihi - Date Received & 18 Temmuz / July 2021 \\
Kabul Tarihi - Date Accepted & 16 Eylül / September 2021 \\
Yayın Tarihi - Date Published & 20 Eylül / September 2021 \\
Yayın Sezonu & Temmuz - Ağustos - Eylül \\
Pub Date Season & July - August - September
\end{tabular}

Atıf / Cite as: Toptaş, Ç. (2021), Cinuçen Tanrıkorur'un İlâhî Formundaki Bestelerinin Biçim Yönünden Tahlîli/ The Formal Analysis of Cinuçen Tanrıkorur's Compositions in Hymnal Form. Turkish Academic Research Review, 6 (3), 10001034. Retrieved from https://dergipark.org.tr/tr/pub/tarr/issue/64962/973007

Intihal / Plagiarism: Bu makale, en az iki hakem tarafından incelenmiş ve intihal içermediği teyit edilmiştir. / This article has been reviewed by at least two referees and confirmed to include no plagiarism. https://dergipark.org.tr/tr/pub/tarr

Copyright (C) Published by Mehmet ŞAHIN Since 2016- Akdeniz University, Faculty of Theology, Antalya, 07058 Turkey. All rights reserved.

Turkish Academic Research Review - Türk Akademik Araştırmalar Dergisi 


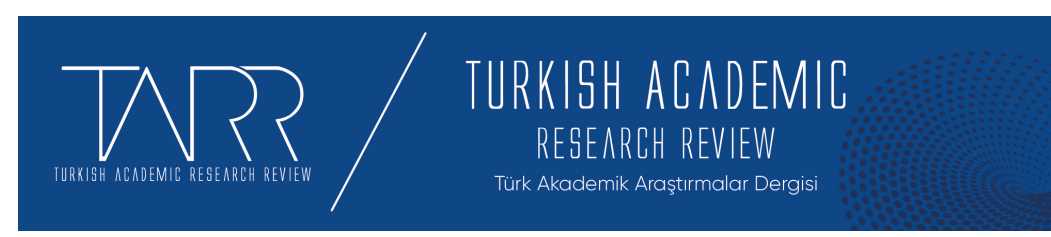

e-ISSN: 2602-2923 Yll/Year: 2021 Cilt/Volume: 6 Sayı/Issue: 3

\title{
Cinuçen Tanrıkorur'un İlâhî Formundaki Bestelerinin Biçim Yönünden Tahlîli
}

\author{
Çağlar TOPTAŞ
}

\section{$\ddot{O} \mathbf{z}$}

Cinuçen Tanrıkorur 20. yy'da yaşamış önemli bir ud virtüözü, besteci ve müzikologdur. Özgün bestecilik anlayışı ile bestelemiş olduğu 505 adet eseri form özellikleri, makam kullanımları, mûsikî tasvîrleri ve ezgi yapılarıyla diğer bestekârlardan ayrıcalıklı özellikler göstermektedir. Bestelemiş olduğu formlardan bazıları; Mevlevî Âyini, Münâcât, Na't, Tevşîh, Durak, Mersiye, İlâhi, Çocuk İlâhisi, Şuğul, Nefes, Peşrev, Saz Semâisi, Medhal, Oyun Havası, Longa, Kâr, Kâr-1 Nâtık, Kârçe, Beste, Ağır Semâi, Yürük Semâi, Fantezi, Şarkı, Destan, Gazel, Ağıt, Türk Film Müziği, Ud Etüdü, Folklorik Etüt, Ninni, Mâni, Çocuk Şarkısı, Marş’tır. Tanrıkorur'un bestelerinde makam, usûl ve seyir bakımından klâsik, geçki ve kompozisyon özellikleri açısından yenilikçidir. Ayrıca bestelerindeki cümleler açık ve net şekilde hissedilmektedir.

$\mathrm{Bu}$ çalışma, Cinuçen Tanrıkorur'un bestecilik anlayışını, Türk din mûsikîsinin en küçük formu olan ilâhî formu üzerinden ortaya koymayı amaçlamaktadır. İlâhî formunda biçim özelliklerinin nasıl kullandığını tespit etmek çalışmadaki diğer amaçlarımızdandır. Çalışma ayrıca Tanrıkorur'un eserlerindeki cümle, bölüm yapılarını inceleyerek, bestekâra ait bestecilik özelliklerini ortaya koymaktadır. Çalışmanın konusu Tanrıkorur'un bestecilik anlayışını ve ilâhî formu kullanım özelliklerinin tesbîti bakımından önemlidir. Çalışmanın evrenini, Tanrıkorur'un besteleri, örneklemini ise, ilâhî formunda seçilmiş 5 adet bestesi oluşturmaktadır.

Çalışmanın yönteminde "Gülçin Yahya Biçim Tahlîli” ve kaynak tarama yöntemleri kullanılmıştır. Cinuçen Tanrıkorur'un seçilen ilâhî formundaki besteleri cümle, bölüm yapıları, eser kurgusu, icra akışı yönleriyle tahlîl edilmiş ve biçim özellikleriyle ortaya konmuştur.

İncelenen ilâhîlerde birbirinden farklı bölüm yapılarının kullanıldığı, esere besteci tarafından güfte hâricinde lafızlar ve nakaratlar eklendiği, ezgi yapılarının sâde bir şekilde makāmı anlattığı, bölümlerde mutlaka makam geçkilerini tercih ettiği tesbit edilmiştir.

Anahtar kelimeler: Cinuçen Tanrıkorur, İlâhî, Makam, Form, Etkin Perde. 


\title{
The Formal Analysis of Cinuçen Tanrıkorur's Compositions in Hymnal Form
}

\begin{abstract}
Cinuçen Tanrıkorur was an important oud virtuoso, composer and musicologist who lived in the 20th century. His 505 pieces of work, which he composed with his unique composition understanding, show distinctive features from other composers with their form features, use of maqams, musical descriptions and melodic structures. Some of the forms he composed; Mevlevi Ceremony, Münâcât, Na't, Tevşîh, Durak, Mersiye, İlahi, Children's İlahi, Şuğul, Nefes, Peşrev, Saz Semaisi, Medhal, Traditional dance music, Longa, Kar, Kar-1 Natik, Karçe, Beste, Ağır Semai, Yürük Semâi, Fantasy, Song, Destan, Gazel, Lament, Turkish Film Music, Oud Etude, Folkloric Etude, Lullaby, Mani, Children's Song, March. In Tanrikorur's compositions, he is classical in terms of maqam, usûl and rhythm, and innovative in terms of transition and composition. In addition, the sentences in his compositions are clearly felt.

This study aims to reveal Cinuçen Tanrıkorur's understanding of composition through the ilâhî form, which is the smallest form of Turkish religious music. One of our other purposes is to determine how he uses form features in his ilâhî form. It is one of our other aims of the study to determine how the form features are used in ilahi form. The study also reveals the compositional characteristics of the composer by examining sentence and section structures of Tanrıkorur's works. The subject of the study is important in terms of determining Tanrlkorur's understanding of composition and the features of using the ilâhî form. The universe of the study consists of Tanrikorur's compositions, and the sample consists of 5 compositions in ilâhî form.

In the method of the study, "Gülçin Yahya Form Analysis" and source scanning methods were used. Cinuçen Tanrıkorur's compositions in the chosen ilâhî form were analyzed in terms of sentence, section structures, playing work fiction, performance flow, and revealed with their form features.

It was determined that different section structures were used in the examined ilâhîs, words and refrains were added to the work by the composer in addition to lyrics, that the melody structures simply explained the maqam, and he definitely preferred the makam passages in the chapters.
\end{abstract}

Keywords: Cinuçen Tanrıkorur, İlahi, Composition, Maqam, Form, Active pitch. 


\section{Structured Abstract}

Cinuçen Tanrikorur is an important figure of the 20th century as an oud virtuoso, composer, writer and intellectual. Cinuçen Tanrikorur has a distinctive oud style unique to his classical style and personality. There are 505 compositions in total (Güngör, 2001) in the religious and ladînî forms of Turkish Music. Some of the forms he composed; Mevlevi Ceremony, Münâcât, Na't, Tevşîh, Durak, Mersiye, İlahi, Children's İlahi, Şuğul, Nefes, Peşrev, Saz Semaisi, Medhal, Traditional dance music, Longa, Kar, Kar-1 Natik, Karçe, Beste, Ağır Semai, Yürük Semâi, Fantasy, Song, Destan, Gazel, Lament, Turkish Film Music, Oud Etude, Folkloric Etude, Lullaby, Mani, Children's Song, March. In Tanrıkorur's compositions, he is classical in terms of maqam, usûl and rhythm, and innovative in terms of transition and composition. In addition, the sentences in his compositions are clearly felt.

Another important issue in the research is the Illahi form. The most known and performed form in Turkish Religious Music from past to present is the İlahi form. İlahies have been the most popular form in both mosque and tekke music. The ilahies mentioned under the titles of mosque and tekke music were also brought into being in lyrics and structures specific to the sects by followers and/or followers of different sects.

It has been seen that Cinuçen Tanrıkorur composed 5 ilahies in the Turkish Religious Music ilahi form and that constitutes the sample of the study, blending the great cultural heritage from the past with a unique style.

Cinuçen Tanrıkorur added "lafiz" and "nakarat" to the lyrics in ilahies. While these words are sometimes performed with the refrain, some of them are used as direct refrains. In addition, it is seen that the form adds licorice parts that are different from its structure.

"Lafizlar" are added (in the form of Yâ Hu) to the lyrics of the ilahi in his niyâz of Acem Bayram. These words are repeated 10 times in total in the work. The piece has a compositional structure in the form of $\mathrm{A}+\mathrm{B}+\mathrm{C}+\mathrm{B}^{1}$. There are 3 chapters and 8 sentences in total in the work. When the active pitches are examined in the work, it is seen that the Nevâ pitch is used a lot.

In Bayâtî Tevşih, on the other hand, unlike the $A+B, A+B+C+B$ form structure of the ilahi form, which is similar to the song form structure, the chanting part was added before moving from the refrain to the licorice part, and a piece structure similar to the composition form is seen. Therefore, a different compositional structure was formed in the form of $\mathrm{A}+\mathrm{B}+$ Terennüm $+\mathrm{C}+\mathrm{B}$. The work has a total of 4 chapters and 14 sentences. It has been observed that the Çargah and Nevâ pitches are the center of the active pitches of the work and that he makes stays and musical phrases in these pitches.

In Dügâh İlâhî, in the last part of the work, there is a section added to the lyrics by Cinuçen Tanrıkorur and performed as "cumhur". The work has a compositional form in the form of $\mathrm{A}+\mathrm{B}+$ Terennüm of the ilahi form. There are 2 chapters and 6 sentences in total in the work. It has been seen that the effective pitches in the work are Dügâh and Çargah and these pitches are the center of melody.

In Gülizâr İlâhî, there are changes in the weighing structures in accordance with the structure in the lyrics of the work. The part of the piece, which is used as a refrain and also as a decision, was added to the lyrics by Cinuçen Tanrikorur. The piece resembles the compositional form of the ilahi form in the form of $\mathrm{A}+\mathrm{B}$ (Zemin + Nakarat), and it has been observed that it diversifies as various variations are added. There are 2 chapters and 10 sentences in total in the work. It has been seen that the Cargah pitch is located in the center of Ezgi, and the Hüseyni pitch is the pitch that is in the center of both transition and another tune.

It has been observed that there are multiple "meyan" parts in the form of $\mathrm{A}+\mathrm{B}+\mathrm{C}$ $+\mathrm{B}+\mathrm{C}^{1}+\mathrm{B}+\mathrm{C}^{2}+\mathrm{B}+\mathrm{C}^{3}+\mathrm{B}$ in Hijaz İlâhî. In this composition, he remained faithful to the maqam structure and made transitions to different maqams in meyan 
and was enriched with the ilahi maqam. The refrain, which is performed in the introductory part of the work and in the turns, was added to the ilahi by Cinuçen Tarınkorur. The work has a total of 6 chapters, 6 sentences and 6 repeated nakarat. It has been understood that the Nim hicaz and Hüseyni pitches, which are the effective pitches in the work, are used more than the Nevâ pitch, which are the strongest of the maqam, and they are the frets in the center of Ezgi.

Cinuçen Tanrikorur's understanding of composition in his ilahi form is different and innovative from the ilahies composed by composers in other ilahi forms, and the use of other pitches both in the center of the melody and as a transition, as well as the theoretically decisive and strong pitch of the form, strengthens the structure of the maqam, as well as in the narration of the maqam. It is seen that it can serve as an example and creates a new and useful idea in ilahi form, form structure and composition.

\section{Giriș}

Cinuçen Tanrıkorur Ud virtüözü, bestekâr, yazar, fikir insanı olarak 20. Yüzyılın önemli bir şahsiyetidir. Cinuçen Tanrıkorur'un klâsik üslûba ve nev’i şahsına mahsus ayrı bir ud tavrı vardır. Türk Mûsikîsinin dini ve lâdînî formlarında toplamda 505 adet (Güngör, 2001) bestesi bulunmaktadır. Bestelemiş olduğu formlardan bazıları; Mevlevî Âyini, Münâcât, Na't, Tevşîh, Durak, Mersiye, İlâhi, Çocuk İlâhisi, Şuğul, Nefes, Peşrev, Saz Semâisi, Medhal, Oyun Havası, Longa, Kâr, Kâr-1 Nâtık, Kârçe, Beste, Ağır Semâi, Yürük Semâi, Fantezi, Şarkı, Destan, Gazel, Ağıt, Türk Film Müziği, Ud Etüdü, Folklorik Etüt, Ninni, Mâni, Çocuk Şarkısı, Marş'tır. Tanrıkorur'un bestelerinde makam, usûl ve seyir bakımından klâsik, geçki ve kompozisyon özellikleri açısından yenilikçidir. Ayrıca bestelerindeki cümleler açık ve net şekilde hissedilmektedir.

Araştırmada bir diğer önemli husus olan konu da İlâhî formudur. Geçmişten günümüze Türk Din Mûsikîsinde en çok bilinen ve icrâ edilen form ilâhî formudur. “İlâhî” lügatte; “Allah’a ait” (Uzun, 2000, s. 64) demektir. Devellioğlu (Devellioğlu, 2013, s. 655) sözlük çalışmasında, ilâhîyi; “Allah'a mensup, Tanrı ile ilgili” şeklinde tarif etmektedir. Süleyman Uludağ tasavvuf terimi olarak ilâhîyi, besteli tasavvufî şiirler” (Uludağ, 2012, s. 183) olarak ifade etmiştir. İlâhîler mübarek günler, geceler ve aylar için farklı isimler altında tasnif edilirler. Bununla ilgili Onur Akdoğu kitabında şöyle bir tasnifte bulunmuştur;

"Dini aylar ile ilgili olarak, Kerbela olayını konu edinen Muharrem İlâhîsini, Safer ayını konu edinen Safer İlâhîlerini, Peygamber Efendimizin (SAV) doğumunu konu edinen Rebîü'l Evvel - Rebîu’l Ahîr İlâhîlerini, Günahlardan arınmayı konu edinen

Turkish Academic Research Review - Türk Akademik Araştırmalar Dergisi 
Cemâziyel-evvel ve Cemâziyel-ahîr ilâhîlerini, Receb ayını konu edinen Receb İlâhîlerini, Şaban ayını konu edinen Şaban İlâhîlerini, Ramazan ayının konu edinmesiyle Ramazan ilâhîlerini” (Akdoğu, 1996, s. 337) bu doğrultuda sınıflandırmıştır.

İlâhîler, tasavvufî şiirlerden seçilerek, her makam ve usûlde bestelenmişlerdir. "İlâhîler, ilâhî aşkı anlatmaktadır" (Kaçar, Türk Mûsikîsi Rehberi, 2012, s. 322) ve "İbâdet edilen her yerde okunabilir." (Özalp, 1992, s. 48) İlâhîler, hem câmi, hem de tekke mûsikîsinde en fazla rağbet edilen form olmuştur. Câmi ve tekke mûsîkisi başlıkları altında bahsedilen ilâhîler de farklı tarîkatların müntesip ve/veya muhiblerince tarîkatlere özgü güfte ve yapılarda vücuda getirilmişlerdir. İlâhîler konusuna, icra edildikleri mahale, içeriklerine ve güftelerine göre Tevhid İlâhîsi, Münâcât, Nâ't, Tevşih, Mersiye, Durak, Savt, Nefes, Şuğul gibi farklı isimler ile ifade edilirler. İlâhîler, ibâdet esnasında ubûdiyet, zühd, takvâ, zikir, Allah aşkı ve Peygamber sevgisini pekiş̧irmek maksadıyla, besteli ve/veya irticalen okunur.

İlâhîlerle ilgili bazı tarîkatlerde farklı isimlendirmeler kullanılmaktadır. Kadirilerde; Devran, Uşşakiler ve Dusûkilerde; İlâhî, Bektaşilerde; Nefes, Gülşenilerde; Savt olarak isimlendirilmektedir. İlâhîler ayrıca güftelerde icra edildiği tarîkatın önderlerinin ve imamlarını da konu edinebilirler. Bununla ilgili olarak Özcan "Tarikatların benimsediği tasavvufî̀ düşünce o tarîkatın âyininde, dolayısiyle zikir esnasında icra edilen mûsikîsinde hissedildiğini” (Özcan, 2011, s. 384) ifade etmektedir.

Bir formun en önemli özelliği de o forma has olan kurucu yapılardır. Bunların başında biçim konusu gelmektedir. Biçim, lügatte; şekl olarak ifade edilmektedir (Devellioğlu, 2013, s. 1459). Ayverdi biçimi; Bir şeyin bütünüyle gösterdiği şekil ve nispet, bir şeyin şekli bakımından kuruluşunun bütünü (Ayverdi, 2010) olarak tanımlamaktadır. Biçim, Kaçar'ın kitabında hem mûsikîdeki kullanımı hem de biçim tahlîli olarak açıklamıştır. Bir mûsikî eserindeki iç yapısı ve dış yapısı, iç ve dış kurgusudur. Ezgi, usûl ve güfte yapılarıdır. Biçim tahlîli ise; bu yapıyı ayrıntılı olarak öğelerine ayırarak cümle, bölüm, makam, usûl, söz yönleriyle incelemek ve çözümlemektir (Kaçar, 2020, s. 57).

Problem Cümlesi: Cinuçen Tanrıkorur'un ilâhî formundaki bestelerinin biçim yönünden nasıl özellikler sergilemektedir? 


\section{Alt Problemler:}

1. Acem Bayram Niyâzı'nın biçim özellikleri nasıldır?

1.1.Acem Bayram Niyâzı'na ait cümle ve bölüm yapıları nasıldır?

1.2. Acem Bayram Niyâzı'na ait eser kurgusu nasıldır?

1.3. Acem Bayram Niyâzı'na ait icrâ akışı nasıldır?

2. Bayâtî Tevşih'e ait biçim özellikleri nasıldır?

2.1.Bayâtî Tevşih'e ait cümle ve bölüm yapıları nasıldır?

2.2.Bayâtî Tevşih'e ait eser kurgusu nasıldır?

2.3. İcrâ akışı nasıldır?

3. Dügâh İlâhî’ye ait biçim özellikleri nasıldır?

3.1.Dügâh İlâĥ̂’ye ait cümle ve bölüm yapıları nasıldır?

3.2.Dügâh İlâhî’ye ait eser kurgusu nasıldır?

3.3. İcrâ akışı nasıldır?

4. Gülizâr İlâhî’ye ait biçim özellikleri nasıldır?

4.1.Gülizâr İlâhî’ye ait cümle ve bölüm yapıları nasıldır?

4.2.Gülizâr İlâhî’ye ait eser kurgusu

4.3.İcrâ akışı nasıldır?

5. Hicâz İlâhî’ye ait biçim özellikleri nasıldır?

5.1.Hicâz İlâhî’ye ait cümle ve bölüm yapıları nasıldır?

5.2.Hicâz İlâhî’ye ait eser kurgusu

5.3. İcrâ akışı nasıldır?

Araştırmanın Amacı: Bu araştırma Cinuçen Tanrıkorur'un bestecilik özelliklerini, bestecilik anlayışını, bestelemiş olduğu ilâhî formundaki eserlerindeki cümle ve bölüm yapılarını, ezgi hareketlerini, eser kurgularını ve icrâ akışını daha detaylı olarak ortaya koymak amacıyla yapılmıştır.

Araștırmanın Önemi: Bu araştırma, Türk Mûsıkîsi'nin 20. Yy.' da yaşamış önemli bestekârlarından biri olan Cinuçen Tanrıkorur'un, bestecilik anlayışını, İlâhi formunda bestelemiş olduğu eserlerinin biçim yönüyle daha detaylı olarak tahlîl edilmesi, ayrıca cümle, bölüm kurgularını, bölümlere ait çeşitli ezgi yapılarını nasıl kullandığını ortaya koyulması açısından ve alanda yapılan ilk çalışma olması bakımından önemlidir.

Araștırmanın Evren ve Örneklemi: Cinuçen Tanrıkorur'un ilâhî formunda bestelemiş olduğu tüm eserleri çalışmanın evrenini; bestelediği ilâhî eserleri içerisindeki 5 adet ilâhî çalışmanın örneklemini oluşturmaktadır.

Turkish Academic Research Review - Türk Akademik Araştırmalar Dergisi https://dergipark.org.tr/tr/pub/tarr 
Sınırlılıklar: Cinuçen Tanrıkorur tarafından yazılmış nota nüshalarından oluşmuş, cümle ve bölüm yapılarıyla farklılıklar gösteren 5 adet ilâhînin biçim açısından tahlîli ile sınırlandırılmıştır.

\section{2- ARAȘTIRMANIN YÖNTEMI}

Cinuçen Tanrıkorur'un İlâhî formundaki bestelerinin biçim yönünden tahlîlini inceleyen bu çalışmada kaynak tarama ve Gülçin Yahya Kaçar Tahlîl Yöntemleri kullanılmıştır. İncelenecek olan ilâhîler "Acem Bayram Niyâzı", "Bayâtî Tevşih", "Dügâh İlâhî", "Gülizâr İlâhî", "Hicâz İlâhî" olmak üzere toplam 5 adetten oluşmaktadır. Çalışmadaki eserlerin notaları, Kaynak tarama yöntemi ile Gülç̧in Yahya Kaçar arşivinden faydalanılarak sağlanmıştır. Eserlerin tamamı, eserlerin bestekârı Cinuçen Tanrıkorur' un kendi el yazısı notalarıdır.

Araştırmanın en önemli parçasını oluşturan Gülçin Yahya Kaçar Tahlîl Yöntemleri ile, Eserlerin Türk mûsikîsi bakış açısı ve öğeleri ile, mûsikîmizin zenginliğini ve inceliklerini bizzat Türk mûsikîsi nazariyat yapısına uygun bir şekilde, kendi içinde bulunan, temel unsurlardan oluşan, çeşitli basamaklar ile analiz araçlarından faydalanılarak tespitler sağlanmıştır. Çalışmada biçim tahlîli yapılırken, birbirine benzeyen cümleler üslü ifadelerle gösterilmiştir.

İcra ve eser tahlîli olarak 2 ana başlıktan oluşan Gülçin Yahya Kaçar biçim tahlîli, yine 5 alt başlık içinde Kaçar'ın kitabında izah edilerek açıklanmıştır. Araştırmanın problemini oluşturan İlâhî formundaki eserlerin tahlîline yönelik olarak "form ve biçim özelliklerinin tahlîli” kapsamında yer alan eser kurgusu ve icra akışı terminolojileri ve bunun uygulamaları çalışmada kullanılmıştır.

Eser kurgusu, Kaçar'ın kitabında şu şekilde açıklanmıştır; Eserdeki cümlelerin, bölümlerin sıralanış biçimini, ezgiye eşlik eden güfteyi, güftenin hangi cümlede kaç ölçü kullanılarak ezgilendirildiğini, cümlenin usûlünü ve usûl geçkilerini, cümlelerden meydana gelen bölümlere verilen adların neler olduğunu, saz paylarını, köprü görevi gören bağlantı ezgilerini ya da bağlantı kelimelerini, bölümlerdeki makam seyirlerinin neler olduğunu gösteren, eserin biçim yönünden hem iç hem de dış dinamiklerini, düzenini ifade eden bir terimdir (Kaçar, 2020, s. 6).

Eser kurgusu gösterimi ile ilgili olarak örnek eserin tamamı kitapta gösterilmesine karşın, Zemin + Nakarat + Meyan + Nakarat biçim yapısına sahip, Düyek usûlünde ve Uşşak makamındaki Şarkı formundaki bu eserin yalnızca zemin bölümü örnek olarak şu şekildedir: 
8/8u - 4ö

I ( A ) Zemin Bölümü - Nevâ perdesinde kalış

$1 . \mathrm{m}-\mathrm{Z}$

Tabloda örnek olarak 8/8u olarak gösterilen kısım eserin usûlünü, 4ö olarak yanında gösterilen kısım ölçü sayısını, I olarak gösterilen kısım bölüm sayısını, (A) olarak gösterilen kısım cümle kısmını, 1.m olarak gösterilen kısmın güfteye ait olan mısrayı ve Z (zemin) olarak gösterilen kısmın bölüm adı olarak belirtilmektedir.

Bir diğer önemli terminoloji olarak belirtilen ve Araştırma için önem arz eden unsur da icra akışıdır. İcra akışı Kaçar'ın kitabında şu şekilde ifade edilmiştir; Eserin icra edilirken tâkip ettiği güzergâhı ifade etmektedir. Sözsüz eserlerde bölümler arası geçişleri, dönüşleri, tekrarları; sözlü eserlerde: saz ve söz birlikteliği ile tâkip edilen yolu, güzergâhı anlatır. Bölümler arası geçişleri, dönüşleri ve tekrarları ile eserin icrasındaki saz-söz trafiğini ifâde eden terimdir (Kaçar, 2020, s. 7).

Eser kurgusunda rastladığımız tabloya benzer öğelerden oluşan İcra akış tablosunda, eser kurgusunda örnek olarak gösterilen, biçim yapısı Zemin + Nakarat + Meyan + Nakarat' tan oluşan eserin tablo hali şu şekildedir:

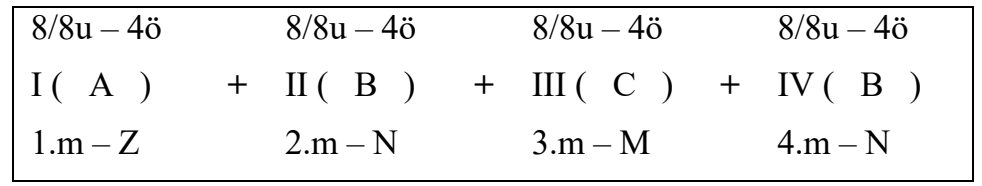

Eserlerin tahlîli yapılırken, bestekârın, ezgi yapısını oluştururken yoğun olarak kullandığı ve diğer perdelerle mukayese edildiğinde daha belirgin olarak tekrar edilen, sık kullanılan perdelerin olduğu tespit edilmiştir. Bu perdeler Gülçin Yahya Kaçar tarafından etkin perdeler olarak tanımlanmıştır. Bu tanım ayrıca Kaçar ve Aydın'ın makalesinde şu şekilde ifade edilmiştir; "Makam seyri içinde kullanım süreleri ve sıklıkları ile diğer perdelere göre ön plana çıkan, makâmın seyir özelliğinde öncü görev üstlenerek seyrine yön veren, makâmın karakteristik özelliğini belirleyen ve kimliğini oluşturan perdeleri “etkin perdeler" olarak tanımlamaktadır” (Kaçar \& Aydın, 2020, s. 1779).

Gülçin Yahya Kaçar biçim tahlîlinde kullanılan semboller, tamamıyla Türk mûsikîsi nazariyatında kullanılan, Türk mûsikîsi türleri ve beste biçimlerini kapsayan geniş ölçekli araçlardan oluşmaktadır. Bunlar; cümleler, bölümler, bısra sayıları, usûl, ölçü sayıları, aranağme, bağlantı, genişleme (ve çeşitleri), giriş sazı, hâne, koda, meyan,

Turkish Academic Research Review - Türk Akademik Araştırmalar Dergisi 
mülâzime, nakarat, serbest, sonuç, terennüm (ve çeşitleri), saz terennümü, zemin, zeyl, bağlantı mısra1, dolap, köprü, lafız, saz payı ve teslim gibi önemli sembollerdir. $\mathrm{Bu}$ sembollerin ayrıca harfler, rakamlar, işaretler ve varyasyonlara göre değişen, üstlü sayılarla ifade edilen çeşitleri bulunmaktadır. İlâhî formundaki eserlerlerin kurgusu ve icrâ akışının sâde ve kolayca aktarılması sürecinde "Gülçin Yahya biçim tahlîlinde tanımlanan semboller ve işâretlerden bâzıları kullanılmıştır.

Sembollerden bazıları şu şekilde gösterilmiştir:

\begin{tabular}{|l|l|}
\hline Motifler: & $\mathrm{a}, \mathrm{b}, \mathrm{c}, \mathrm{a}^{1}, \mathrm{~b}^{1}, \mathrm{c}^{1} \mathrm{vb}$. küçük harfle ve üst simge ile yazılır. \\
\hline Cümleler: & $\mathrm{A}, \mathrm{B}, \mathrm{C}, \mathrm{A}^{1}, \mathrm{~B}^{1}, \mathrm{C}^{1}$ vb. olarak büyük harfle parantez içinde yazılır. \\
\hline Bölümler: & I, II, III, IV, V vb. olarak Romen rakamlarıyla sol başa yazılır. \\
\hline Misra sayıları: & $1 . \mathrm{m} ., 2 . \mathrm{m} ., 3 . \mathrm{m}$. vb. olarak alta yazılır \\
\hline Usûl: & $7 / 8 \mathrm{u}, 5 / 8 \mathrm{u}$ vb. olarak üste yazılır. \\
& \\
\hline
\end{tabular}

\section{3- BULGULAR VE YORUMLAR}

\subsection{Acem Bayram Niyâzı'nın biçim tahlîli}

Çalışmanın 1. Alt problemini oluşturan eser, güftesi Mehmet Âkif Ersoy’a, bestesi Cinuçen Tanrıkorur'a ait olan Düyek usûlünde ve Acem makamındaki Acem Bayram Niyazı adlı eser,

\section{$\underline{\text { Kullanilan Perdeler }}$}

Acem makamındaki Bayram Niyazı adlı ilâhîde farklı kullanım sıklığına bağlı olarak 10 ayrı perdenin kullanıldığı tespit edilmiştir. Bu perdeler pestten tize doğru; Rast, Dügâh, Segâh, Çargâh, Nevâ, Hüseynî, Acem, Gerdâniye, Muhayyer ve Sünbüle'dir. Aşağıdaki şekilde perde altlarında bulunan sayılar, o perdenin beste içinde kaç defa kullanıldığını göstermektedir. 


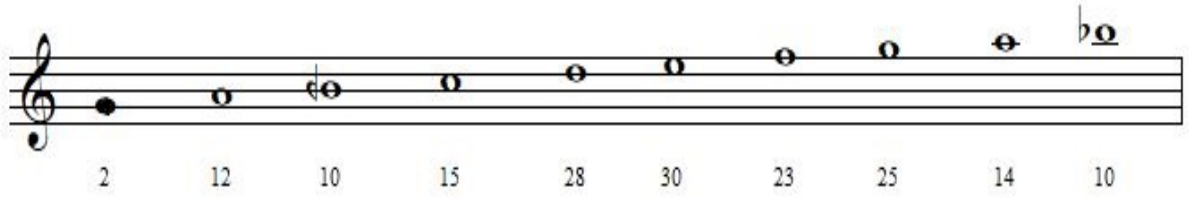

\section{$\underline{\text { Etkin Perdeler }}$}

Acem makamındaki Bayram Niyazı adlı ilâhîde; Dügâh, Çargâh, Nevâ, Acem ve Muhayyer perdeleri etkin perde olarak kullanılmıştır. Bestekâr ezgi hareketlerini bu perdeler etrafında şekillendirmiştir. Eserin makamı gereği bu perdeler, Acem makamında perdenin sık kullanımdan ziyade üzerinde ezgi hareketlerinin yoğunluğunun bulunduğu, geçki, yarım ve asma kalışların yapıldığı perdelerdir.

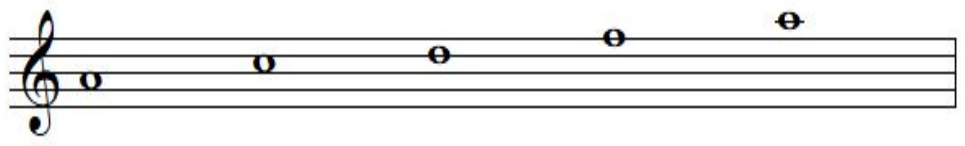

\subsubsection{Acem Bayram Niyâzı'na ait cümle ve bölüm yapıları}

\section{Cümle Yapılart}

I. bölümü 2 cümleden ( $\mathrm{A}+\mathrm{B}$ ) oluşmaktadır. Eserde güfteye ek olarak Cinuçen Tanrıkorur tarafinda eklenen "Lafızlar" bulunmaktadır. "Yâ Hû" şeklindeki terennümler "lz" olarak ayrıca belirtilmiştir. A cümlesinin sonunda "Yâ Hû" lafzı kullanılmıştır. 4/8 uzunluğunda kullanılmıştır.

\section{$\underline{\text { Bölüm Yapılart }}$}

Eser toplam 4 bölümden oluşmaktadır. 4. bölüm Nakarat kısmı olup, 2. bölümün tekrarı niteliğindedir.

Eserin I. bölümü eserin zemin kısmını oluşturmaktadır ve cümle yapıları bölümünde belirtildiği üzere 2 cümleden ( $\mathrm{A}+\mathrm{B}$ ) oluşmaktadır.

Eserin II. bölümü, eserin nakarat kısmı olup, yine I. bölümde olduğu gibi 2 cümleden $\left(\mathrm{C}^{1}+C^{1}\right)$ oluşmaktadır. Çalışmanın yöntem bölümünde belirtildiği ve ilâhîde de görüldüğü üzere aynı ezgi ikinci tekrarda farklı bir güfteyle bestelendiği için $\mathrm{C}^{2}$ olarak belirtilmiştir.

Turkish Academic Research Review - Türk Akademik Araştırmalar Dergisi https://dergipark.org.tr/tr/pub/tarr 
1010 Cinuçen Tanrıkorur'un İlâhî Formundaki Bestelerinin Biçim Yönünden Tahlîli

Eserin III. bölümü, eserin meyân kısmı olup, I. ve II. bölümde olduğu gibi 2 cümleden ( D + E ) oluşmaktadır.

Eserin II. bölümü, meyandan sonraki nakarat kısmı olup, II. bölümde aynı olduğu, güfte farklılıkları bulunduğundan dolayı yine 2 cümleden $\left(\mathrm{C}^{1}+\mathrm{C}^{1}\right)$ oluşmaktadır.

\subsubsection{Acem Bayram Niyâzı'na ait Eser Kurgusu}

Acem Bayram Niyâzı'na ait eser kurgusu aşağıdaki tabloda gösterilmiştir.

\section{Eser Kurgusu}

\begin{tabular}{|c|c|}
\hline $\begin{array}{l}\text { 8/8u-4ö } \\
\text { I }\left(\begin{array}{c}\mathrm{A} \\
\text { 1.m-(Yâ Hû }) l z-Z\end{array}\right.\end{array}$ & Zemin Bölümü / Acem makāmı dizisi \\
\hline $\begin{array}{c}8 / 8 \mathrm{u}-4 \ddot{0} \\
\left(\begin{array}{c}\mathrm{B} \\
2 . \mathrm{m}-\mathrm{Z}\end{array}\right)\end{array}$ & Zemin Bölümü / Acem makāmı dizisi \\
\hline $\begin{array}{l}\text { 8/8u -4ö } \\
\text { II }\left(\begin{array}{c}C^{1} \\
\text { 3.m- (Yâ Hû }) \text { Iz-N }\end{array}\right.\end{array}$ & $\begin{array}{l}\text { Nakarat Bölümü / Çargâh’ta Çargâh dörtlüsü, Acem perdesinde } \\
\text { Çargâh beşlisi + Dügâh’ta Uşşak dörtlüsü (Acem makamı) }\end{array}$ \\
\hline $\begin{array}{c}\text { 8/8u -4ö } \\
\left(\begin{array}{c}C^{1} \\
4 . \mathrm{m}-\mathrm{N}\end{array}\right)\end{array}$ & $\begin{array}{l}\text { Nakarat Bölümü / Çargâh’ta Çargâh dörtlüsü, Acem perdesinde } \\
\text { Çargâh beşlisi + Dügâh’ta Uşşak dörtlüsü(Acem makamı) }\end{array}$ \\
\hline $\begin{array}{l}\text { 8/8u-4ö } \\
\text { III }\left(\begin{array}{c}\mathrm{D} \\
\text { 5.m-(Yâ Hû)lz-M }\end{array}\right.\end{array}$ & $\begin{array}{l}\text { Meyân Bölümü / Dügâh’ta Rast dörtlüsü (Isfahan makamı Geçkisi) + } \\
\text { Nevâ'da Rast 5'lisi }\end{array}$ \\
\hline $\begin{array}{c}\text { 8/8u-4ö } \\
\left(\begin{array}{c}\mathrm{E} \quad) \\
\text { 6.m-(Yâ Hû)lz-M }\end{array}\right.\end{array}$ & Meyân Bölümü / Müstear makamı geçkisi \\
\hline $\begin{array}{l}\text { 8/8u -4ö } \\
\text { II }\left(\begin{array}{c}\mathrm{C}^{1} \\
\text { 7.m- (Yâ Hû) Iz-N }\end{array}\right.\end{array}$ & $\begin{array}{l}\text { Nakarat Bölümü / Çargâh’ta Çargâh dörtlüsü + Acem perdesinde } \\
\text { Çargâh beşlisi + Dügâh’ta Uşşak dörtlüsü (Acem makamı) }\end{array}$ \\
\hline $\begin{array}{c}8 / 8 \mathrm{u}-4 \ddot{0} \\
\left(\begin{array}{c}\mathrm{C}^{1} \\
8 . \mathrm{m}-\mathrm{N}\end{array}\right)\end{array}$ & $\begin{array}{l}\text { Nakarat Bölümü / Çargâh’ta Çargâh dörtlüsü + Acem perdesinde } \\
\text { Çargâh beşlisi + Dügâh’ta Uşşak dörtlüsü (Acem makamı) }\end{array}$ \\
\hline
\end{tabular}




\subsubsection{Acem Bayram Niyâzı'na ait İcrâ Akışı}

Acem Bayram Niyâzı'na ait icrâ akışı aşağıdaki tabloda gösterilmiştir.

\section{$\underline{\text { İcrâ Akıș }}$}

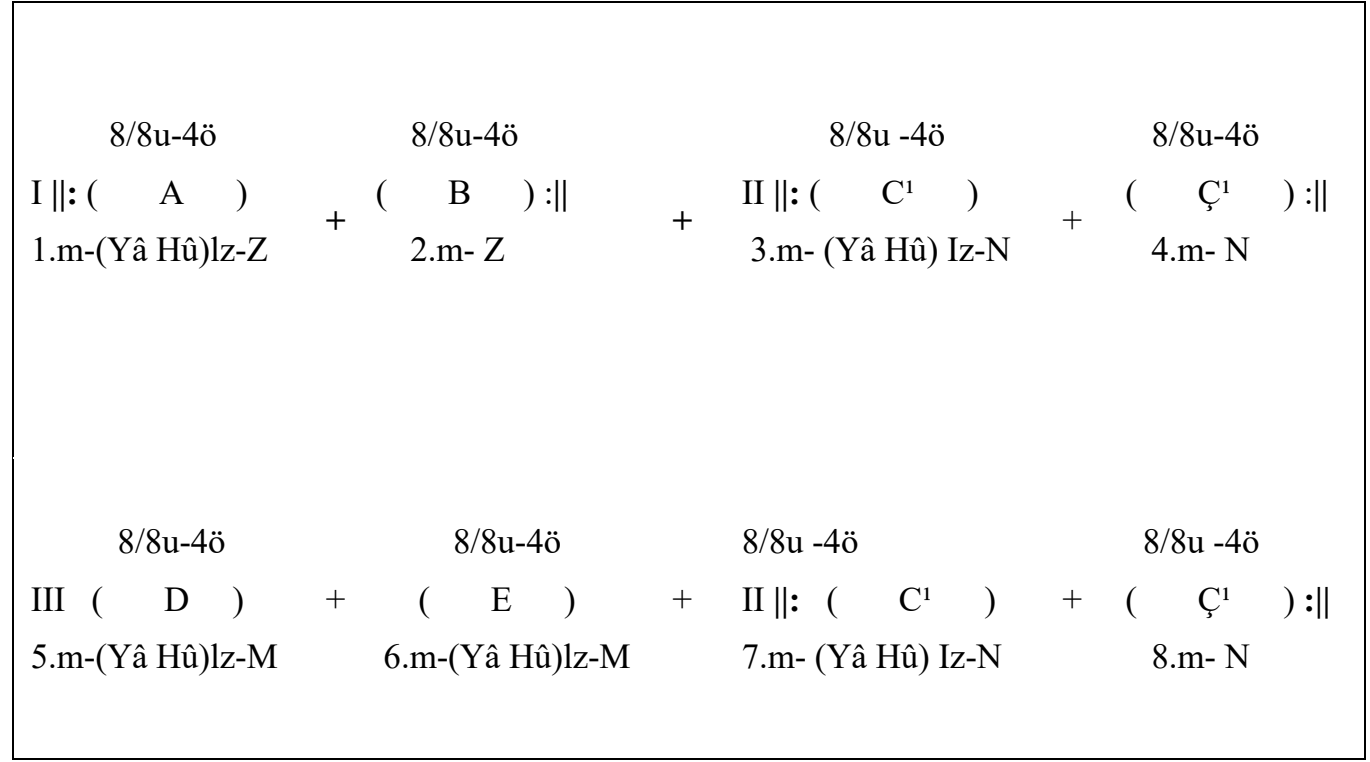

\section{ACEM BAYRAM NIYAZI}

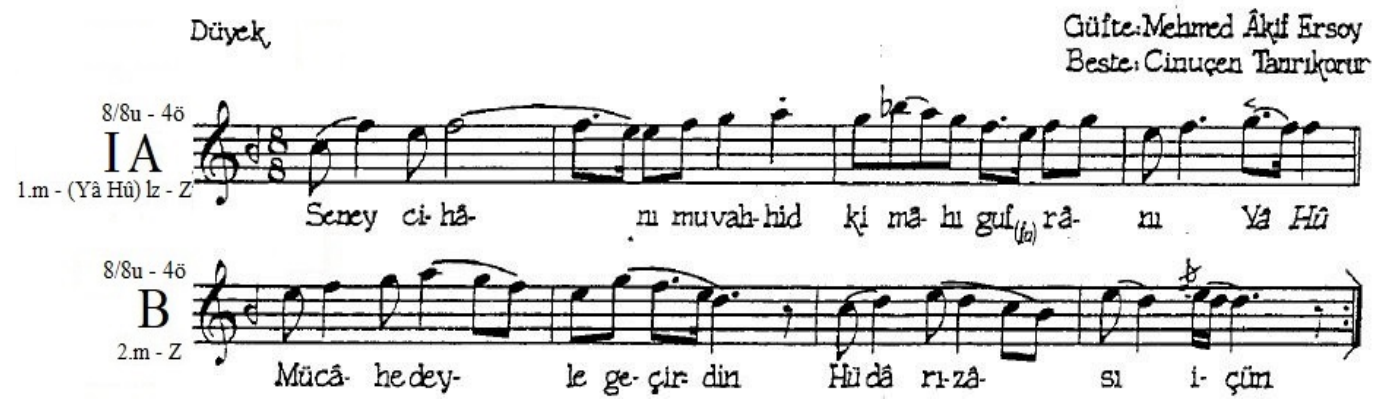

Turkish Academic Research Review - Türk Akademik Araştırmalar Dergisi 

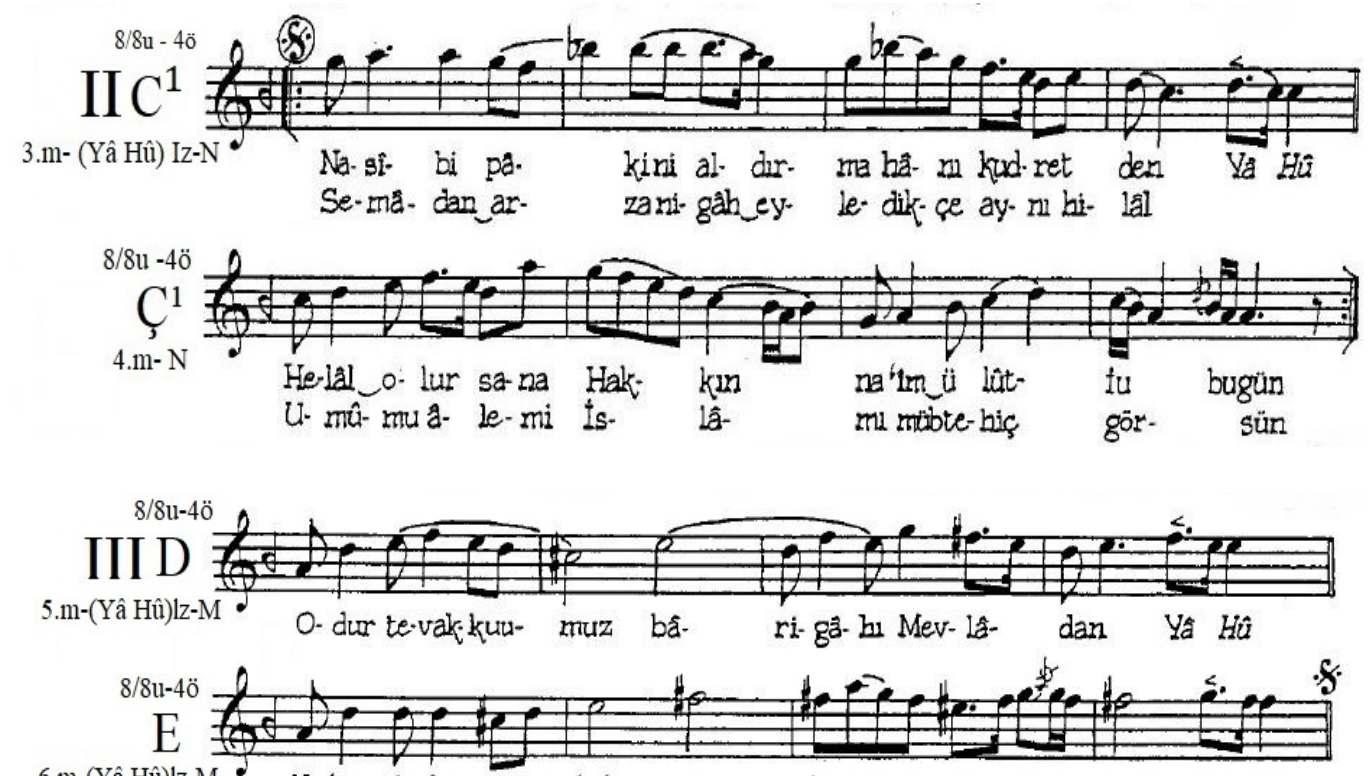

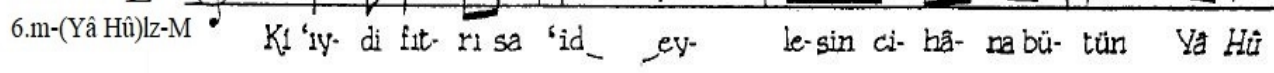

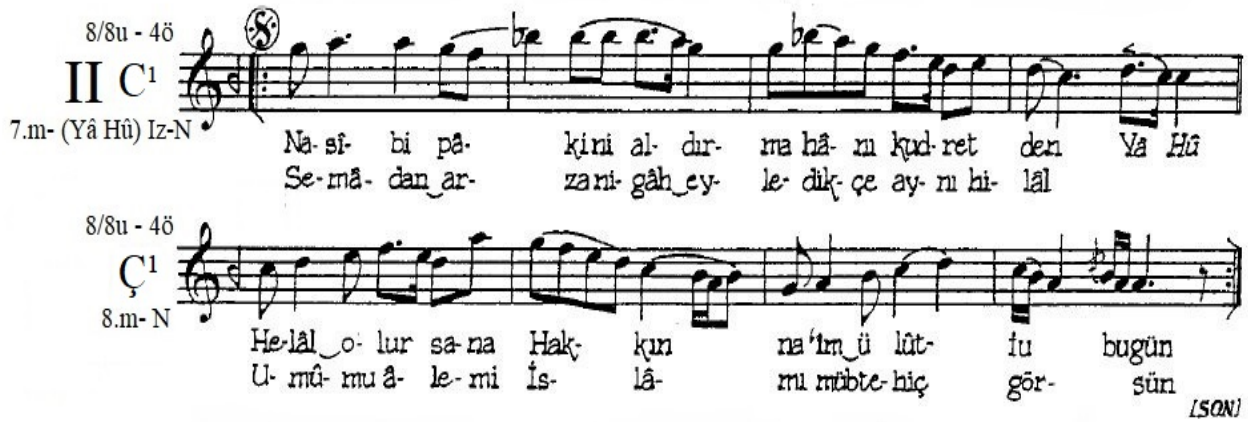

Sen ey cihân-ı muvahhid ki mâh-ı gufrân

Mücâhedeyle geçirdin Hüdâ rıâsı içün

Nasib-i pâkini aldırma hân-ı kudretten

Helâl olur sana Hakkın naim ü lüftu bugün

Odur tevakkuumuz bârigâh-ı Mevlâdan

Ki'zyd-i fitrl said eylesin cihana bütün

Semâdan arza nigâh eyledikçe aynı hilâl

Umum-u âlem-i İslâmı mübtehiç görsün

\subsection{Bayâtî Tevşih'e ait biçim tahlîli}

Çalışmanın 2. alt problemini oluşturan güftesi Azîz Mahmud Hüdâyî'ye, bestesi

Cinuçen Tanrıkorur'a ait olan Mevlevî Devr-i Revânı usûlünde ve Bayâtî 
makamındaki Tevşih, eserin bestekârı Cinuçen Tanrıkorur tarafından bizzat yazılmış olup, notası Devlet Korosu Arşiv Programı (Notam 1.0) arşivinden alınmıştır.

\section{$\underline{\text { Kullanulan Perdeler }}$}

Bayâtî makamındaki Tevşih’te farklı kullanım sıklığına bağlı olarak 9 ayrı perdenin kullanıldığı tespit edilmiştir. Bu perdeler pestten tize doğru; Rast, Dügâh, Segâh, Çargâh, Nevâ, Hüseynî, Acem, Gerdâniye ve Muhayyer'dir. Aşağıdaki şekilde perde altlarında bulunan sayılar, o perdenin beste içinde kaç defa kullanıldığını göstermektedir.

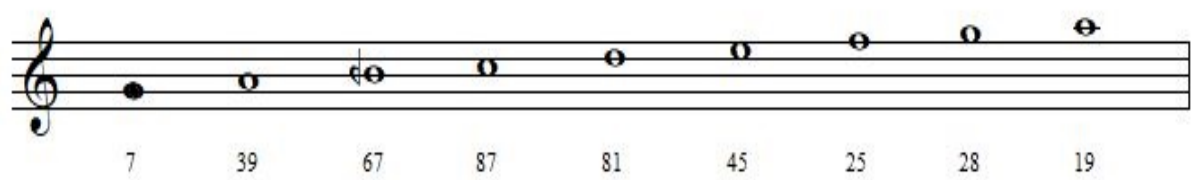

\section{$\underline{\text { Etkin Perdeler }}$}

Bayâtî Makamındaki Tevşih'te; Dügâh, Çargâh, Nevâ, Acem ve Muhayyer perdeleri etkin perde olarak kullanılmıştır. Bestekâr ezgi hareketlerini bu perdeler etrafında şekillendirmiştir. Eserin makamı gereği bu perdeler, Bayâtî makamında ezgi hareketliliği yoğunluğu bulunan, üzerinde geçki, yarım ve asma kalışların yapıldığı, seyre yön veren perdelerdir.

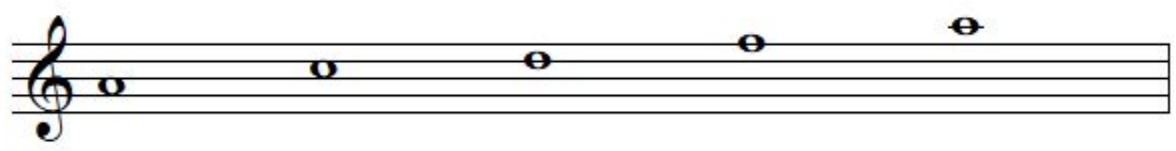

\subsubsection{Bayâtî Tevşih'e ait cümle ve bölüm yapıları}

\section{Cümle Yapılart}

Eserde Toplam 8 Cümle $\left(\mathrm{A}^{1}+\mathrm{B}^{1}+\mathrm{C}^{1}+\mathrm{C}^{1}+\mathrm{D}+\mathrm{E}+\mathrm{F}+\mathrm{G}\right)$ bulunmaktadır. Eserin tekrar işaretine uyarak dönüşünün yapıldığı Nakarat kısmına $\left(\mathrm{C}^{1}+\mathrm{C}^{1}\right)$ ek olarak Cinuçen Tanrıkorur tarafindan esere eklenen Lafzi Terennüm kısmı $(\mathrm{D}+\mathrm{E})$ bulunmaktadır. Her mısra 1 cümleyi ifade etmektedir.

\section{$\underline{\text { Bölüm Yapılart }}$}

Eser toplam 4 bölümden oluşmaktadır. Eserin I. bölümü zemin kısmıdır. $\mathrm{A}^{1}+\mathrm{B}^{1}$ cümlelerinin birleşmesinden oluşur.

Eserin II. bölümü nakarat kısmıdır. $\mathrm{C}^{1}+C^{1}$ cümlelerinin birleşmesinden oluşur. 
Eserin III. bölümü Cinuçen Tanrıkorur tarafından güfteye eklenen, lafzi terennümden oluşan nakarat kısmıdır. D + E cümlelerinin birleşmesinden oluşur. Eser dönüşler tamamlandıktan sonra bu bölümde karar verir.

Eserin IV. bölümü meyan kısmıdır. F $+\mathrm{G}$ cümlelerinin birleşmesinden oluşur. $\mathrm{Bu}$ bölümün bitiminde dönüş işareti ile II. bölüme, nakarat kısmına dönülür. III. bölümün icrası ile eser karar verir.

\subsubsection{Bayâtî Tevşih'e ait Eser Kurgusu}

Bayâtî Tevşih'e ait eser kurgusu aşağıdaki tabloda gösterilmiştir.

\section{Eser Kurgusu}

\begin{tabular}{|c|c|}
\hline $\begin{array}{c}14 / 8 \mathrm{u}-20 \ddot{ } \\
\mathrm{I}\left(\begin{array}{c}\mathrm{A}^{1} \\
1 . \mathrm{m}-\mathrm{Z}\end{array}\right)\end{array}$ & $\begin{array}{l}\text { Zemin Bölümü / Dügâh’ta Bayâti makam dizisi + Nevâ'da } \\
\text { Buselik Beşlisi }\end{array}$ \\
\hline 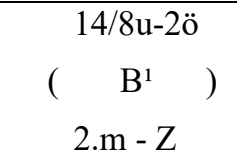 & $\begin{array}{l}\text { Zemin Bölümü / Nevâ'da Buselik Beşlisi + Nevâ'da Hicaz } \\
\text { Beşlisi }\end{array}$ \\
\hline 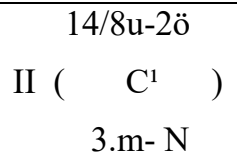 & $\begin{array}{l}\text { Nakarat Bölümü / Çargâh’ta Çargâh Beşlisi + Çargâh’ta } \\
\text { Nikriz Çeşnisi }\end{array}$ \\
\hline $\begin{array}{c}\text { 14/8u-2ö } \\
\left(\begin{array}{c}\mathrm{C}^{1} \\
4 . \mathrm{m}-\mathrm{N}\end{array}\right)\end{array}$ & Nakarat Bölümü / Dügâh’ta Bayati makam dizisi \\
\hline $\begin{array}{c}14 / 8 \mathrm{u}-20 \ddot{ } \\
\mathrm{I}\left(\begin{array}{c}\mathrm{A}^{2} \\
5 . \mathrm{m}-\mathrm{Z}\end{array}\right)\end{array}$ & $\begin{array}{l}\text { Zemin Bölümü / Dügâh’ta Bayâti makam Dizisi + Nevâ'da } \\
\text { Buselik Beşlisi }\end{array}$ \\
\hline 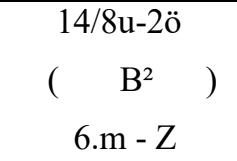 & $\begin{array}{l}\text { Zemin Bölümü / Nevâ'da Buselik Beşlisi + Nevâ'da Hicaz } \\
\text { Beşlisi }\end{array}$ \\
\hline II $\left(\begin{array}{c}14 / 8 \mathrm{u}-20 \ddot{C} \\
\mathrm{C}^{2}\end{array}\right)$ & $\begin{array}{l}\text { Nakarat Bölümü / Çargâh’ta Çargâh Beşlisi + Çargâh’ta } \\
\text { Nikriz çeşnisi }\end{array}$ \\
\hline $\begin{array}{c}\text { 14/8u-2ö } \\
\left(\begin{array}{c}\mathrm{C}^{2} \\
8 . \mathrm{m}-\mathrm{N}\end{array}\right)\end{array}$ & Nakarat Bölümü / Dügâh’ta Bayati makam dizisi \\
\hline
\end{tabular}




\begin{tabular}{|c|c|}
\hline III $\left(\begin{array}{c}14 / 8 \mathrm{u}-20 \ddot{ } \\
\mathrm{D} \\
\mathrm{N}\end{array}\right)$ & $\begin{array}{l}\text { Nakarat Bölümü / Dügâh’ta Bayati Makam Dizisi + Nevâ'da } \\
\text { Buselik Beşlisi }\end{array}$ \\
\hline $\begin{array}{c}14 / 8 \mathrm{u}-20 \ddot{0} \\
\left(\begin{array}{c}\mathrm{E} \\
\mathrm{N}\end{array}\right)\end{array}$ & $\begin{array}{l}\text { Nakarat Bölümü / Rast'ta Nikriz Çeşnisi + Dügâh'ta Bayati } \\
\text { çeşnisi }\end{array}$ \\
\hline $\begin{array}{c}14 / 8 \mathrm{u}-20 \ddot{ } \\
\mathrm{IV}\left(\begin{array}{c}\mathrm{F} \\
9 . \mathrm{m}-\mathrm{M}\end{array}\right)\end{array}$ & $\begin{array}{l}\text { Meyân Bölümü / Muhayyer'de Simetrik Beyâti Çeşnisi + } \\
\text { Nevâ'da Rast çeşnisi }\end{array}$ \\
\hline $\begin{array}{c}14 / 8 \mathrm{u}-20 \ddot{ } \\
\left(\begin{array}{c}\mathrm{G} \\
\text { 10.m }-\mathrm{M}\end{array}\right.\end{array}$ & $\begin{array}{l}\text { Meyân Bölümü Çargâh’ta Nikriz Çeşnisi (Karciğar Çeşnisi) } \\
\text { + Nevâ'da Hicaz Beşlisi }\end{array}$ \\
\hline II $\left(\begin{array}{c}14 / 8 \mathrm{u}-2 \ddot{\mathrm{o}} \\
\mathrm{C}^{3}\end{array}\right)$ & $\begin{array}{l}\text { Nakarat Bölümü / Çargâh’ta Çargâh Beşlisi + Çargâh'ta } \\
\text { Nikriz çeşnisi }\end{array}$ \\
\hline $\begin{array}{c}\text { 14/8u-2ö } \\
\left(\begin{array}{c}C^{3} \\
12 . m-N\end{array}\right)\end{array}$ & Nakarat Bölümü / Dügâh’ta Bayati makam Dizisi \\
\hline III $\left(\begin{array}{c}14 / 8 \mathrm{u}-20 \ddot{ } \\
\mathrm{D} \\
\mathrm{N}\end{array}\right)$ & $\begin{array}{l}\text { Nakarat Bölümü / Dügâh’ta Bayati Makam Dizisi + Nevâ'da } \\
\text { Buselik Beşlisi }\end{array}$ \\
\hline $\left.\begin{array}{c}14 / 8 \mathrm{u}-20 \ddot{ } \\
\mathrm{E}\end{array}\right)$ & $\begin{array}{l}\text { Nakarat Bölümü / Rast'ta Nikriz Çeşnisi + Dügâh'ta Bayati } \\
\text { Çeşnisi }\end{array}$ \\
\hline
\end{tabular}

\subsubsection{Bayâtî Tevşih'e ait İcrâ Akışı}

Bayâtî Tevşih'e ait icrâ akışı aşağıdaki tabloda gösterilmiştir.

Turkish Academic Research Review - Türk Akademik Araştırmalar Dergisi https://dergipark.org.tr/tr/pub/tarr 


\section{İcrâ Akısı}

\begin{tabular}{|c|c|c|c|c|c|c|c|c|c|}
\hline \multicolumn{3}{|l|}{ 14/8u-20̈ } & \multicolumn{2}{|r|}{ 14/8u-2ö } & \multicolumn{3}{|c|}{ 14/8u-2ö } & & 14/8u-2ö \\
\hline $\mathrm{I}\left(\begin{array}{c}\mathrm{A}^{1} \\
1 . \mathrm{m}-\mathrm{Z}\end{array}\right)$ & & + & ( & $\left.\begin{array}{c}\mathrm{B}^{1} \\
2 . \mathrm{m}-\mathrm{Z}\end{array}\right)$ & + & II $\|:\left(\underset{3 . m-N}{C^{1}}\right.$ & ) & + & $\left(\begin{array}{c}\mathrm{C}^{1} \\
4 . \mathrm{m}-\mathrm{N}\end{array}\right): \|$ \\
\hline 14/8u-2ö & & & & 14/8u-20̈ & & $14 / 8 u-2 \ddot{o}$ & & & 14/8u-2ö \\
\hline $\mathrm{I}\left(\begin{array}{c}\mathrm{A}^{2} \\
5 . \mathrm{m}-\mathrm{Z}\end{array}\right)$ & & + & ( & $\left(\begin{array}{c}\mathrm{B}^{2} \\
6 . \mathrm{m}-\mathrm{Z}\end{array}\right)$ & + & II $\|: \underset{7 . m-N}{C^{2}}$ & ) & + & 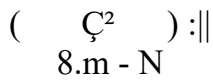 \\
\hline $14 / 8 u-20 \ddot{~}$ & & & & 14/8u-20̈ & & 14/8u-20̈ & & & 14/8u-2ö \\
\hline III $\|: \underbrace{}_{N} \underset{N}{D}$ & ) & + & ( & $\left.\begin{array}{l}\mathrm{E} \\
\mathrm{N}\end{array}\right): \|$ & + & 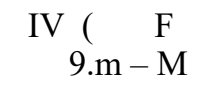 & ) & + & $(\underset{10 . m-M}{G})$ \\
\hline $\mathrm{II} \|: \underset{11 . \mathrm{m}-\mathrm{N}}{\mathrm{C}^{3}}$ & ) & + & ( & $\begin{array}{c}\text { 14/8u-20̈ } \\
\left.C^{C^{3}}\right): \| \\
12 . \mathrm{m}-\mathrm{N}\end{array}$ & + & III $\|:{ }_{N}^{14 / 8 u-20 ̈ ~}$ & ) & + & $\left(\begin{array}{c}14 / 8 \mathrm{u}-20 \ddot{0} \\
\mathrm{E} \\
\mathrm{N}\end{array}\right): \|$ \\
\hline
\end{tabular}

BAYATİ TEVȘîH
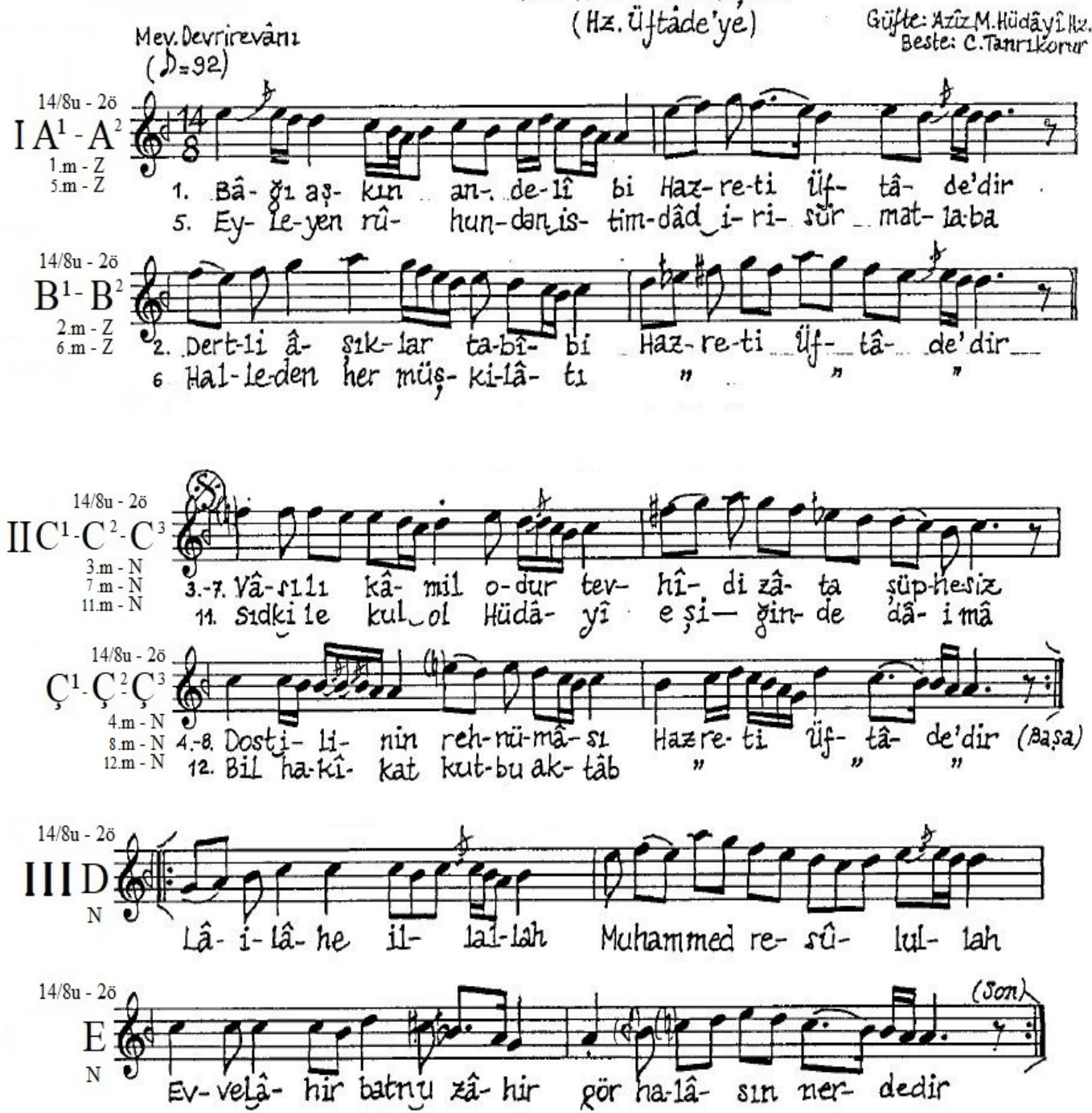


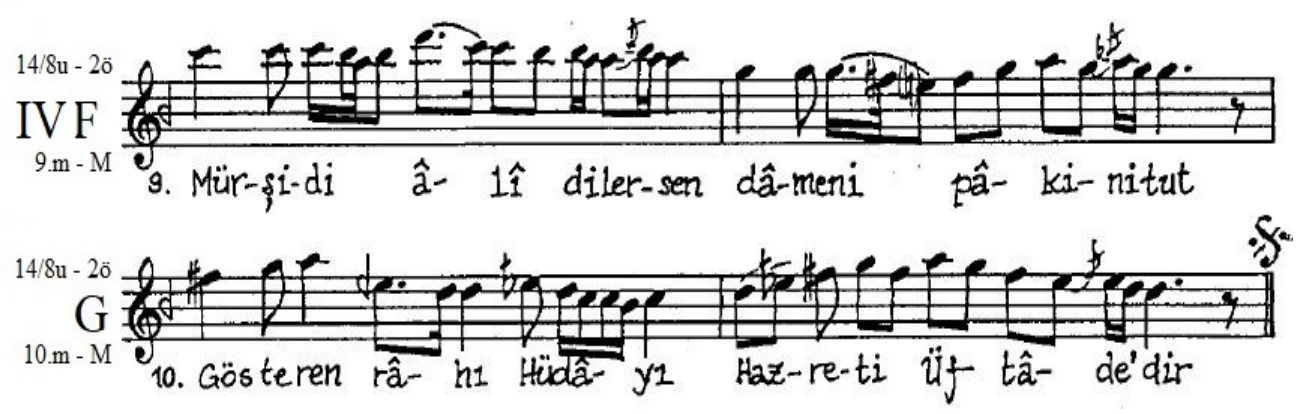

Bağ-ı aşkın andelîbi Hazret-i Üftâde'dir Dertli âşılklar tabîbi Hazret-i Üftâde'dir

Vâsıl-ı kâmil odur tevhîd-i Zâta şüphesiz Dost ilinin rehnümâsı Hazret-i Üftâde'dir

Eyleyen rûhundan istimdâd irişür matlaba Halleden her müşkilâtı Hazret-i Üftâde'dir

Mürşid-i âli dilersen dâmen-i pâkini tut Gösteren râh-ı Hüdâyı Hazret-i Üftâde'dir

Sidk ile kul ol Hüdâyi eşiğinde dâima Bil hakîkat kutb-i aktâb Hazret-i Üftâde'dir

\subsection{Dügâh İlâhî’ye ait biçim tahlîli}

Çalışmanın 3. alt problemini oluşturan güftesi Azîz Mahmud Hüdâyî’ye, bestesi Cinuçen Tanrıkorur'a ait olan Düyek usûlünde ve Dügâh makamındaki ilâhî, eserin bestekârı Cinuçen Tanrıkorur tarafından bizzat yazılmış olup, notası Devlet Korosu Arşiv Programı (Notam 1.0) arşivinden alınmıştır.

\section{$\underline{\text { Kullanilan Perdeler }}$}

Dügâh makamındaki İlâhı̂’de farklı kullanım sıklığına bağlı olarak 11 ayrı perdenin kullanıldığg tespit edilmiştir. Bu perdeler pestten tize doğru; Zirgüle, Dügâh, Segâh, Dik Kürdî, Çargâh, Dik Çargâh (Koma Diyezli Çargâh perdesi), Hicâz, Hüseynî, Acem, Gerdâniye ve Şehnaz'dır. Aşağıdaki şekilde perde altlarında bulunan sayılar, o perdenin beste içinde kaç defa kullanıldığını göstermektedir. 


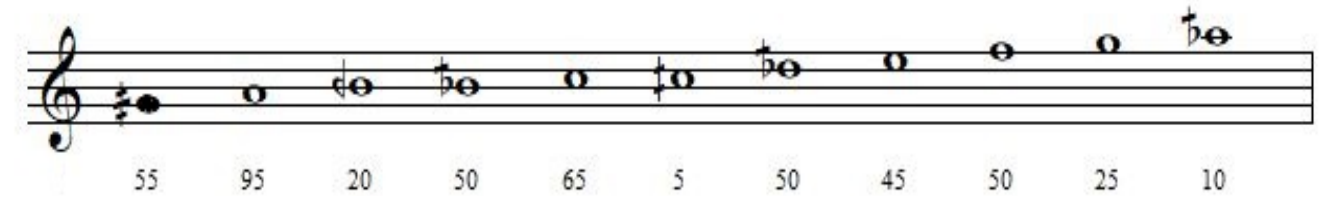

\section{$\underline{\text { Etkin Perdeler }}$}

Dügâh makamındaki ilâhî'de; Dügâh ve Çargâh perdeleri etkin perde olarak kullanılmıştır. Bestekâr ezgi hareketlerini bu perdeler etrafında şekillendirmiştir. Eserin makamı gereği bu perdeler, Dügâh makamında üzerinde geçki, yarım ve asma kalışların yapıldığı, ezgi hareketlerine yön veren perdelerdir.

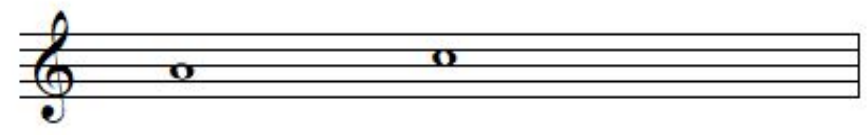

\subsubsection{Dügâh İlâhî’ye ait cümle ve bölüm yapıları}

\section{Cümle Yapılart}

Eserde toplam 4 Cümle $\left(\mathrm{A}^{1}+\mathrm{B}^{1}+\mathrm{C}+\mathrm{C}\right)$ bulunmaktadır. Eserin $\mathrm{A}^{1} 1$ tekrar, $\mathrm{B}^{1}$ cümlesi 2 tekrardan oluşmaktadır. Cinuçen Tanrıkorur tarafından esere eklenen lafzi terennüm kısmı $(\mathrm{C}+\mathrm{C})$ bulunmaktadır.

\section{$\underline{\text { Bölüm Yapıları }}$}

Eser toplam 2 bölümden oluşmaktadır. Eserin I. bölümü zemin kısmıdır. $\mathrm{A}^{1}+\mathrm{B}^{1}$ cümlelerinin birleşmesinden oluşur. $\mathrm{A}^{1}$ bölümü tek tekrar, $\mathrm{B}^{1}$ çift tekrar edilir.

Eserin II. bölümünü Cinuçen Tanrıkorur tarafından esere eklenen lafzi terennüm kısmı oluşturmaktadır. $\mathrm{C}+$ Ç cümlelerinin birleşmesinden oluşur.

\subsubsection{Dügâh İlâhî’ye ait Eser Kurgusu}

Dügâh İlâhî’ye ait eser kurgusu aşağıdaki tabloda gösterilmiştir.

\section{Eser Kurgusu}

\begin{tabular}{|c|c|}
\hline $8 / 8 u-40 ̈$ & \\
\hline I $\left(\begin{array}{c}\left.\mathrm{A}^{1} \quad\right) \\
1.2 \cdot \mathrm{m}-\mathrm{Z}\end{array}\right.$ & $\begin{array}{l}\text { Zemin Bölümü / Dügâh’ta Segâh Çeşnisi + Çargâh’ta Zirgüleli Hicaz } \\
\text { Dizisi (Dügâh Makāmı dizisi) }\end{array}$ \\
\hline $\begin{array}{c}8 / 8 \mathrm{u}-2 \ddot{\mathrm{o}} \\
\left(\quad \mathrm{B}^{1}+\underline{\mathrm{t} 2 \ddot{0}}\right.\end{array}$ & $\begin{array}{l}\text { Zemin Bölümü / Çargâh’ta Zirgüleli Hicaz Dizisi (Dügâh Makāmı } \\
\text { dizisi) }\end{array}$ \\
\hline
\end{tabular}




\begin{tabular}{|c|c|}
\hline 3.4.m-Z & \\
\hline $\begin{array}{c}\text { 8/8u-4ö } \\
\left(\begin{array}{c}\mathrm{C} \\
\mathrm{N}\end{array}\right)\end{array}$ & $\begin{array}{l}\text { Nakarat Bölümü / Dügâh’ta Segâh Çeşnisi + Çargâh’ta Zirgüleli } \\
\text { Hicaz Dizisi (Dügâh Makāmı dizisi) }\end{array}$ \\
\hline $\left.\begin{array}{c}\text { 8/8u-4ö } \\
\text { Ç } \\
\mathrm{N}\end{array}\right)$ & $\begin{array}{l}\text { Nakarat Bölümü / Dügâh’ta Segâh Çeşnisi + Çargâh’ta Zirgüleli } \\
\text { Hicaz Dizisi (Dügâh Makāmı dizisi) }\end{array}$ \\
\hline $\begin{array}{l}\text { 8/8u-4ö } \\
\text { I }\left(\begin{array}{c}\mathrm{A}^{2} \\
\text { 5.6.m }-\mathrm{Z}\end{array}\right)\end{array}$ & $\begin{array}{l}\text { Zemin Bölümü / Dügâh’ta Segâh Çeşnisi + Çargâh’ta Zirgüleli Hicaz } \\
\text { Dizisi (Dügâh Makāmı dizisi) }\end{array}$ \\
\hline $\begin{array}{l}8 / 8 \mathrm{u}-2 \ddot{\mathrm{o}} \\
\left(\begin{array}{l}\mathrm{B}^{2}+\underline{\mathrm{t} 2 \ddot{\mathrm{o}}} \\
\text { 7.8.m }-\mathrm{Z}\end{array}\right)\end{array}$ & $\begin{array}{l}\text { Zemin Bölümü / Çargâh'ta Zirgüleli Hicaz Dizisi (Dügâh Makāmı } \\
\text { dizisi) }\end{array}$ \\
\hline 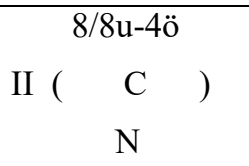 & $\begin{array}{l}\text { Nakarat Bölümü / Dügâh’ta Segâh Çeşnisi + Çargâh’ta Zirgüleli } \\
\text { Hicaz Dizisi (Dügâh Makāmı dizisi) }\end{array}$ \\
\hline $\begin{array}{c}\text { 8/8u-4ö } \\
\left(\begin{array}{c}\mathrm{C} \\
\mathrm{N}\end{array}\right)\end{array}$ & $\begin{array}{l}\text { Nakarat Bölümü / Dügâh’ta Segâh Çeşnisi + Çargâh’ta Zirgüleli } \\
\text { Hicaz Dizisi (Dügâh Makāmı dizisi) }\end{array}$ \\
\hline
\end{tabular}

\subsubsection{Dügâh İlâhî’ye ait İcrâ Akışı}

Dügâh İlâhî’ye ait icrâ akışı aşağıdaki tabloda gösterilmiştir.

\section{$\underline{\text { İrâ Akıșı }}$}

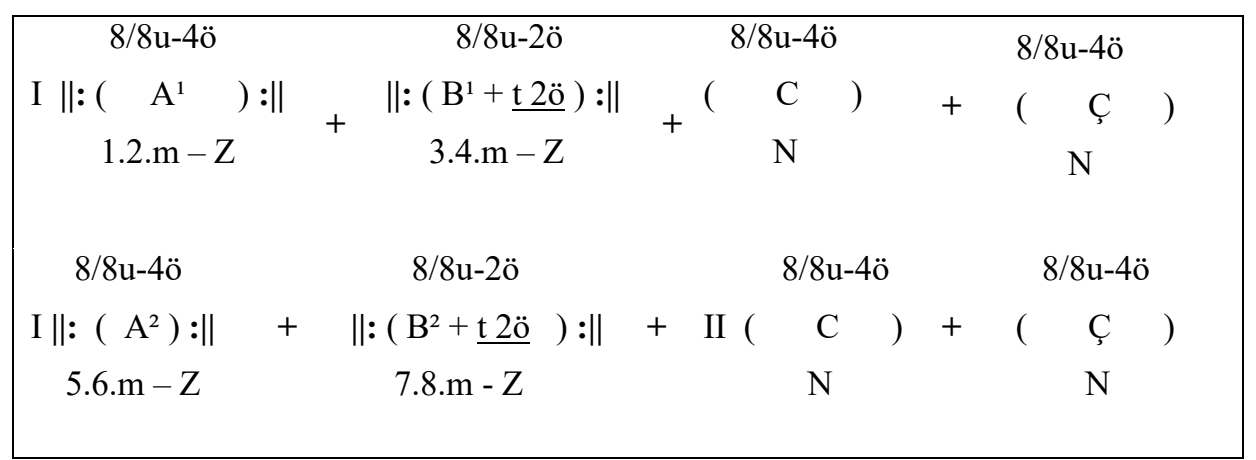

Turkish Academic Research Review - Türk Akademik Araştırmalar Dergisi 


\section{DÜGẢH İAÂHi}
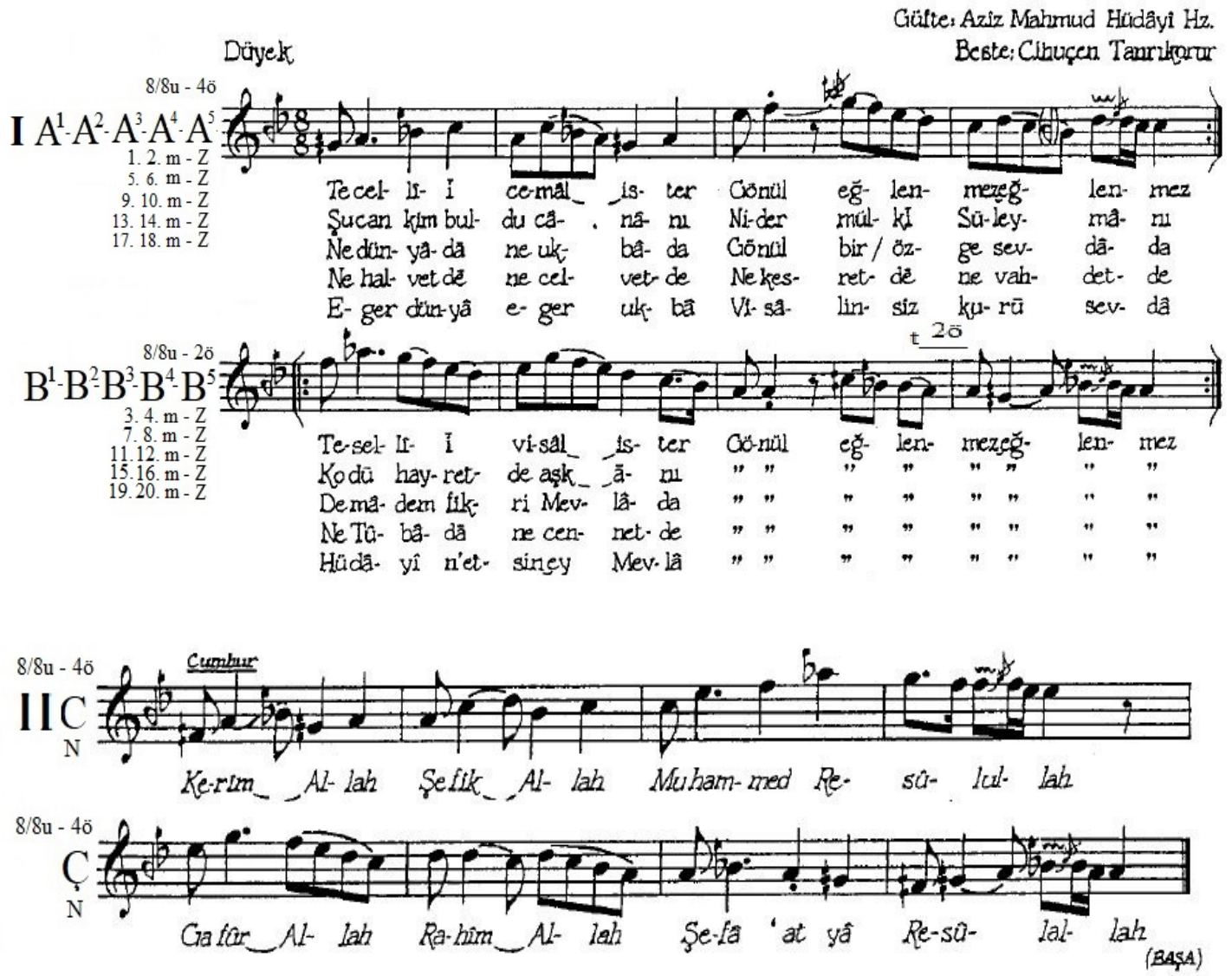

Tecellî-i cemâl ister

Gönül/eğlenmez eğlenmez

Tesellî- $i$ visâl ister

Gönül/eğlenmez eğlenmez

Şu can kim buldu cânânı

Nider mülk-i Süleymân'

Kodü hayretde aşk ânı

Gönül/eğlenmez eğlenmez

Ne dünyâda, ne ukbâda

Gönül bir/özge sevdâda

Demâdem fikri Mevlâda

Gönül/eğlenmez ĕglenmez

Ne halvetde, ne celvetde

Ne kesretde, ne vahdetde

Ne Tübâdâ, ne cennetde

Gönül/eğlenmez eğlenmez

Ĕger dünyâ, eger ukbâ

Visâlinsiz kurü sevdâ 
Hüdâŷ̂ n'etsin ey Mevlâ

Gönül/eğlenmez ĕglenmez

Cumhur

Kerim Allah, Şefik Allah

Muhammed Resûlullah

Gafûr Allah, Rahîm Allah

Şefầ' at yâ Resûlallah

\subsection{Gülizâr İlâhî’ye ait biçim tahlîli}

Çalışmanın 4. alt problemini oluşturan güftesi Azîz Mahmud Hüdâyî’ye, bestesi Cinuçen Tanrıkorur'a ait olan Sofyan usûlünde ve Gülizar makamındaki ilâhî, eserin bestekârı Cinuçen Tanrıkorur tarafından bizzat yazılmış olup, notası Devlet Korosu Arşiv Programı (Notam 1.0) arşivinden alınmıştır.

\section{$\underline{\text { Kullanilan Perdeler }}$}

Gülizar makamındaki ilâhî’de farklı kullanım sıklığına bağlı olarak 9 ayrı perdenin kullanıldığı tespit edilmiştir. Bu perdeler pestten tize doğru; Rast, Dügâh, Segâh, Çargâh, Nevâ, Hüseynî, Eviç, Gerdâniye ve Muhayyer'dir. Aşağıdaki şekilde perde altlarında bulunan sayılar, o perdenin beste içinde kaç defa kullanıldığını göstermektedir.

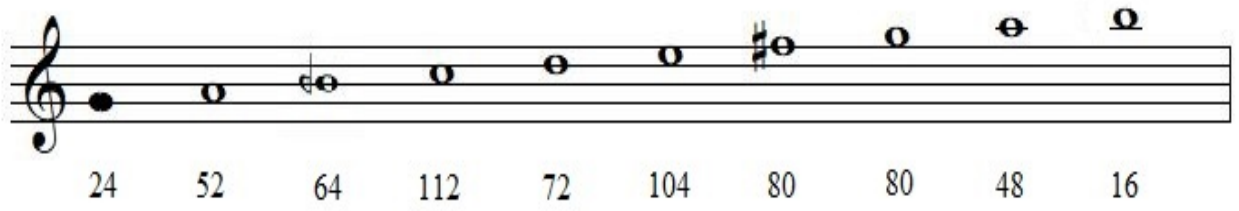

\section{$\underline{\text { Etkin Perdeler }}$}

Gülizar makamındaki ilâhî’de; Dügâh, Çargâh ve Hüseynî perdeleri etkin perde olarak kullanılmıştır. Bestekâr ezgi hareketlerini bu perdeler etrafında şekillendirmiştir. Eserin makamı gereği bu perdeler, Gülizar makamında, makamın karakteristik özelliğini taşıyan, üzerinde geçki, yarım ve asma kalışların bolca kullanıldığı merkezi perdelerdir.

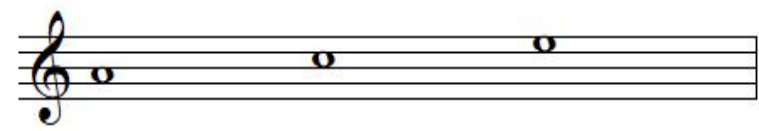

Turkish Academic Research Review - Türk Akademik Araştırmalar Dergisi https://dergipark.org.tr/tr/pub/tarr 


\subsubsection{Gülizâr İlâhî’ye ait cümle ve bölüm yapıları}

\section{Cümle Yapıları}

Eserde Toplam 4 Cümle $\left(\mathrm{A}^{1}+\mathrm{B}^{1}+\mathrm{C}+\mathrm{C}\right)$ bulunmaktadır. Eserin $\mathrm{A}^{1}$ ve $\mathrm{B}^{1}$ cümleleri eser içinde çeşitlenerek $\mathrm{A}^{2}+\mathrm{B}^{2}, \mathrm{~A}^{3}+\mathrm{B}^{3}$ ve $\mathrm{A}^{4}+\mathrm{B}^{4}$ olarak kullanılmaktadır. Cinuçen Tanrıkorur tarafından esere eklenen lafzi terennüm kısmı (C + D) bulunmaktadır. Bu bölüm ayrıca Nakarat olarak kullanılmaktadır.

\section{$\underline{\text { Bölüm Yapılart }}$}

Eser toplam 2 bölümden oluşmaktadır. Eserin I. bölümü zemin kısmıdır. $\mathrm{A}^{1}+\mathrm{B}^{1}$ cümlelerinin birleşmesinden oluşur. $\mathrm{A}^{1}$ ve $\mathrm{B}^{1}$ ayrı ayrı çift tekrar edilir.

Eserin II. bölümünü Cinuçen Tanrıkorur tarafından esere eklenen lafzi terennüm / nakarat kısmı oluşturmaktadır. C + D cümlelerinin birleşmesinden oluşur.

Eserin $\mathrm{A}^{2}+\mathrm{B}^{2}$ cümlelerinden oluşan $\mathrm{I}$. bölümün tekrarı durumunda olan kısmında farklı tartımlar kullanılmıştır. Devamında dönüş işareti ile II. Bölüme dönülmektedir.

Eserin $\mathrm{A}^{3}+\mathrm{B}^{3}$ cümlelerinden oluşan $\mathrm{I}$. bölümün tekrarı durumunda olan kısmında farklı tartımlar kullanılmıştır. Devamında dönüş işareti ile II. Bölüme dönülmektedir.

Eserin $\mathrm{A}^{4}+\mathrm{B}^{4}$ cümlelerinden oluşan I. bölümün tekrarı durumunda olan kısmında farklı tartımlar kullanılmıştır. Devamında dönüş işareti ile II. bölüme dönülmektedir. Bu dönüş ile birlikte eser tamamlanmaktadır.

\subsubsection{Gülizâr İlâhî’ye ait Eser Kurgusu}

Gülizâr İlâhî’ye ait eser kurgusu aşağıdaki tabloda gösterilmiştir.

\section{$\underline{\text { Eser Kurgusu }}$}

\begin{tabular}{|c|c|}
\hline $4 / 4 u-4 \ddot{0}$ & \\
\hline $\begin{array}{c}\mathrm{I}\left(\mathrm{A}^{1}\right) \\
1.2 \mathrm{~m}-\mathrm{Z}\end{array}$ & Zemin Bölümü / Hüseynî'de Uşşak ve Hüseynî Çeşnisi \\
\hline 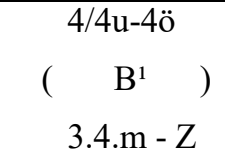 & $\begin{array}{l}\text { Zemin Bölümü / Hüseynî’de Uşşak ve Hüseynî Çeşnisi + Dügâh’ta Hüseynî } \\
\text { Beşlisi (Gülizar makamı) }\end{array}$ \\
\hline 4/4u-4ö & Nakarat Bölümü / Dügâh’ta Hüseynî Beşlisi + Hüseynî'de Uşşak ve Hüseynî \\
\hline II $(\mathrm{C} \quad)$ & Çeşnisi \\
\hline
\end{tabular}




\begin{tabular}{|c|c|}
\hline $\mathrm{N}$ & \\
\hline $\left.\begin{array}{c}4 / 4 \mathrm{u}-4 \ddot{o} \\
\mathrm{D} \\
\mathrm{N}\end{array}\right)$ & $\begin{array}{l}\text { Nakarat Bölümü / Nevâ'da Buselik Çeşnisi + Dügâh’ta Uşşak ve Hüseynî } \\
\text { Çeşnisi (Gülizar makamı) }\end{array}$ \\
\hline $\begin{array}{c}4 / 4 \mathrm{u}-4 \ddot{0} \\
\mathrm{I}\left(\begin{array}{c}\mathrm{A}^{2} \\
\text { 5.6.m }-\mathrm{Z}\end{array}\right)\end{array}$ & Zemin Bölümü / Hüseynî’de Uşşak ve Hüseynî Çeşnisi \\
\hline 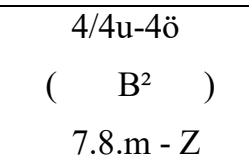 & $\begin{array}{l}\text { Zemin Bölümü / Hüseynî’de Uşşak ve Hüseynî Çeşnisi + Dügâh’ta Hüseynî } \\
\text { Beşlisi (Gülizar makamı) }\end{array}$ \\
\hline II $\left(\begin{array}{c}4 / 4 \mathrm{u}-4 \ddot{0} \\
\mathrm{C}\end{array}\right)$ & $\begin{array}{l}\text { Nakarat Bölümü / Dügâh’ta Hüseynî Beşlisi + Hüseynî’de Uşşak ve Hüseynî } \\
\text { Çeşnisi }\end{array}$ \\
\hline $\left.\begin{array}{c}4 / 4 \mathrm{u}-4 \ddot{0} \\
\mathrm{D} \\
\mathrm{N}\end{array}\right)$ & $\begin{array}{l}\text { Nakarat Bölümü / Nevâ'da Buselik Çeşnisi + Dügâh’ta Uşşak ve Hüseynî } \\
\text { Beşlisi (Gülizar makamı) }\end{array}$ \\
\hline 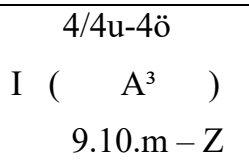 & Zemin Bölümü / Hüseynı̂’de Uşşak ve Hüseynî Çeşnisi \\
\hline 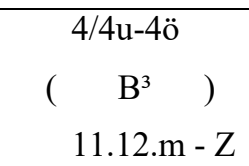 & $\begin{array}{l}\text { Zemin Bölümü / Hüseynî’de Uşşak ve Hüseynî Çeşnisi + Dügâh’ta Hüseynî } \\
\text { beşlisi (Gülizar makamı) }\end{array}$ \\
\hline II $\left(\begin{array}{c}4 / 4 \mathrm{u}-40 \ddot{ } \\
\mathrm{C}\end{array}\right)$ & $\begin{array}{l}\text { Nakarat Bölümü / Dügâh’ta Hüseynî Beşlisi + Hüseynî’de Uşşak ve Hüseynî } \\
\text { çeşnisi }\end{array}$ \\
\hline$\left(\begin{array}{c}4 / 4 \mathrm{u}-4 \ddot{0} \\
\mathrm{D}\end{array}\right)$ & $\begin{array}{l}\text { Nakarat Bölümü / Nevâ'da Buselik Çeşnisi + Dügâh’ta Uşşak ve Hüseynî } \\
\text { Beşlisi (Gülizar makamı) }\end{array}$ \\
\hline $\begin{array}{c}4 / 4 \mathrm{u}-4 \ddot{0} \\
\mathrm{I}\left(\begin{array}{c}\mathrm{A}^{4} \\
13.14 . \mathrm{m}-\mathrm{Z}\end{array}\right)\end{array}$ & Zemin Bölümü / Hüseynî'de Uşşak ve Hüseynî Çeşnisi \\
\hline 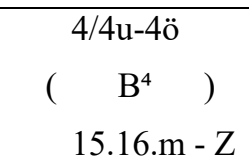 & $\begin{array}{l}\text { Zemin Bölümü / Hüseynî’de Uşşak ve Hüseynî Çeşnisi + Dügâh’ta Hüseynî } \\
\text { Beşlisi (Gülizar makamı) }\end{array}$ \\
\hline 4/4u-4ö & Nakarat Bölümü / Dügâh’ta Hüseynî Beşlisi + Hüseynî’de Uşşak ve Hüseynî \\
\hline
\end{tabular}

Turkish Academic Research Review - Türk Akademik Araştırmalar Dergisi 


\begin{tabular}{|cl}
\hline II ( $\begin{array}{c}\mathrm{C} \\
\mathrm{N}\end{array}$ & beşlisi \\
\hline $\begin{array}{c}\text { 4/4u-4ö } \\
\left(\begin{array}{c}\mathrm{D} \\
\mathrm{N}\end{array}\right.\end{array}$ & $\begin{array}{l}\text { Nakarat Bölümü / Nevâ'da Buselik Çeşnisi + Dügâh'ta Uşşak ve Hüseynî } \\
\text { beşlisi (Gülizar makamı) }\end{array}$
\end{tabular}

\subsubsection{Gülizâr İlâhî’ye ait İcrâ Akışı}

Gülizâr İlâhî’ye ait icrâ akışı aşağıdaki tabloda gösterilmiştir.

\section{$\underline{\text { Icrâ Akıș }}$}

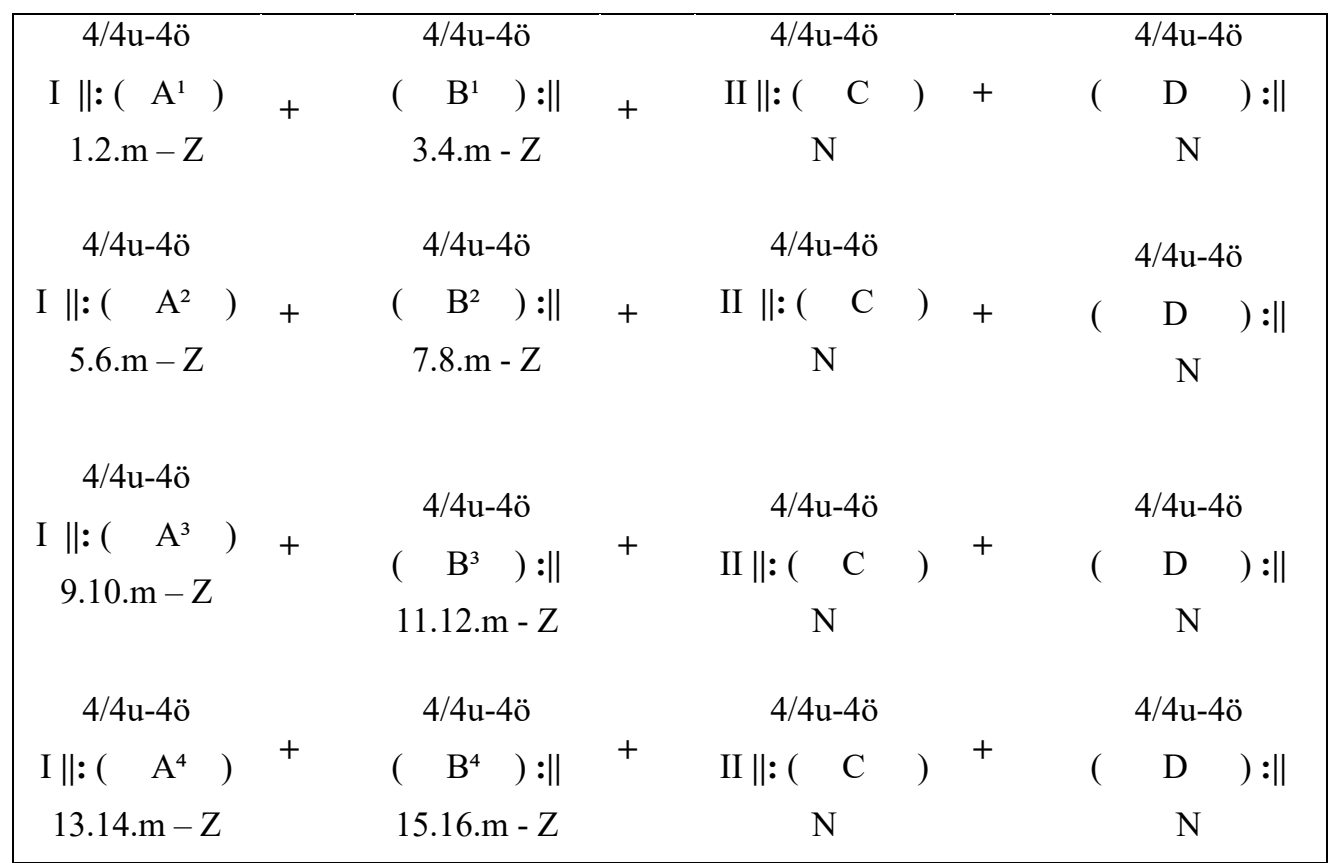



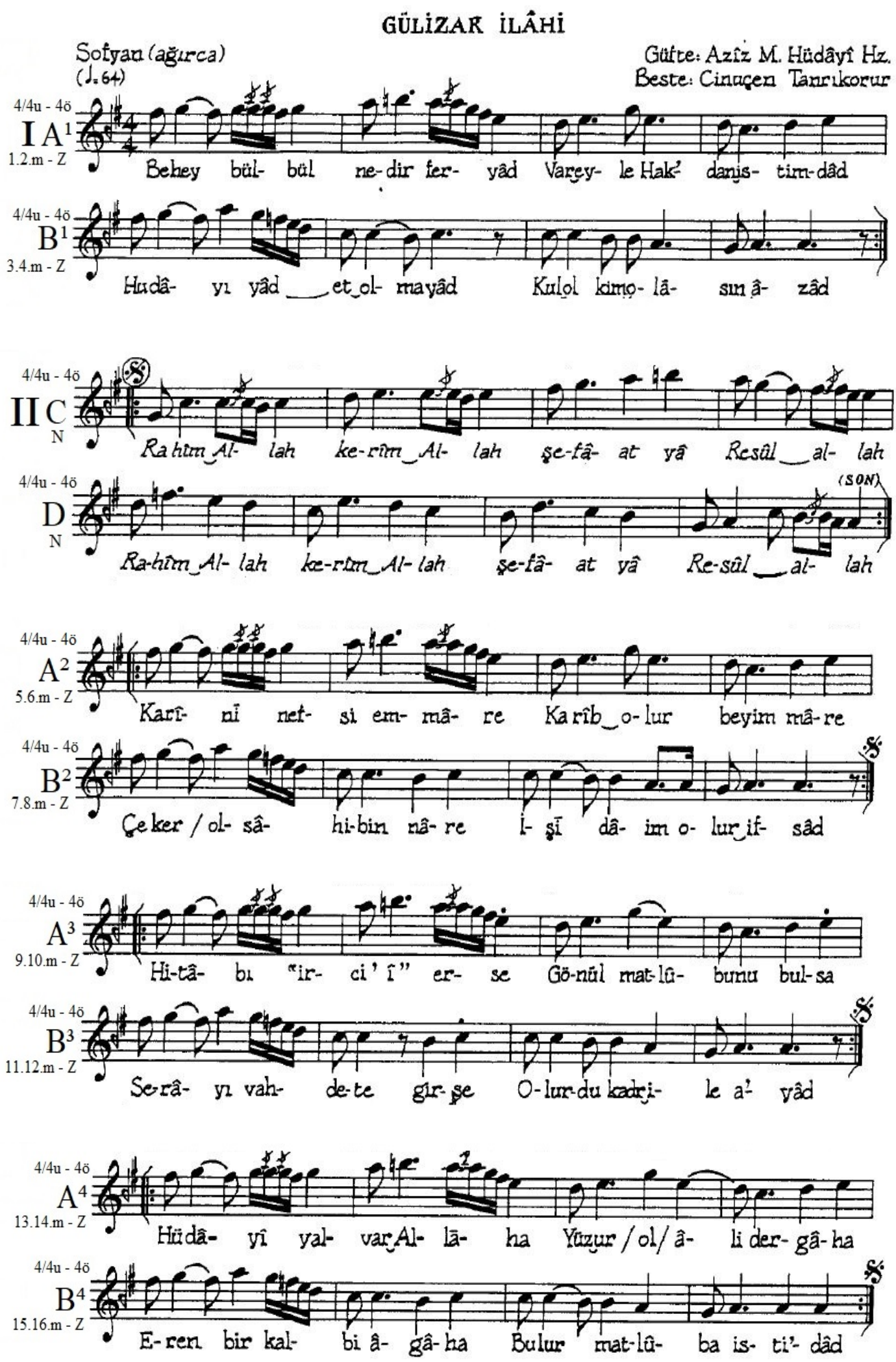

Turkish Academic Research Review - Türk Akademik Araştırmalar Dergisi 
Behey bülbül nedir feryâd

Var eyle Hak'dan istimdâd

Hudâyı yâd et olma yâd

Kul ol kim/olâsın/azâd

Karîn-i nefs-i emmâre

Karib olur beyim mâre

Çeker/ol sâhibin nâre

Işi dâim olur ifsâd

Hitâb-l "irci' î" erse

Gönül matlubunu bulsa

Serây-i vahdete girse

Olurdü kadr ile a'yad

Hüdâŷ̂ yalvar Allâh'a

Yüz ur ol/âli dergâha

Eren bir kalb-i âgâha

Bulur matluba isti'dâd

\subsection{Hicâz İlâhî'ye ait biçim tahlîli}

Çalışmanın 5. alt problemini oluşturan Güftesi Yunus Emre'ye, bestesi Cinuçen Tanrıkorur'a ait olan Nim sofyan usûlünde ve Hicaz makamındaki ilâhî, eserin bestekârı Cinuçen Tanrıkorur tarafından bizzat yazılmış olup, notası Devlet Korosu Arşiv Programı (Notam 1.0) arşivinden alınmıştır.

\section{$\underline{\text { Kullanilan Perdeler }}$}

Hicaz makamındaki İlâhî’de farklı kullanım sıklığına bağlı olarak 9 ayrı perdenin kullanıldığı tespit edilmiştir. Bu perdeler pestten tize doğru; Rast, Dügâh, Dik Kürdî, Nim Hicaz, Nevâ, Hüseynî, Acem, Gerdâniye ve Muhayyer'dir. Aşağıdaki şekilde perde altlarında bulunan sayılar, o perdenin beste içinde kaç defa kullanıldığını göstermektedir.

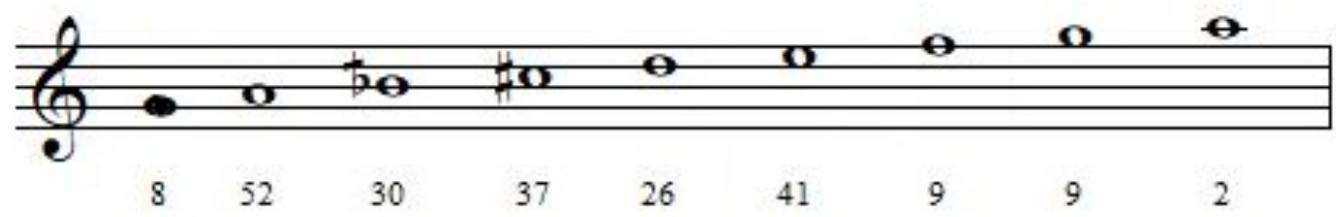




\section{$\underline{\text { Etkin Perdeler }}$}

Hicaz makamındaki ilâhî’de; Dügâh, Nim Hicaz ve Hüseynî perdeleri etkin perde olarak kullanılmıştır. Bestekâr ezgi hareketlerini bu perdeler etrafinda şekillendirmiştir. Eserin makamı gereği bu perdeler, Hicaz makamında sik kullanılan, üzerinde geçki, yarım ve asma kalışların yapıldığı perdelerdir.

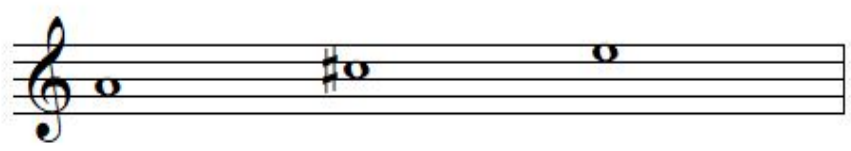

\subsubsection{Hicâz İlâhî’ye ait cümle ve bölüm yapıları}

\section{Cümle Yapıları}

Eserde toplam 6 cümle $(\mathrm{A}+\mathrm{B}+\mathrm{C}+\mathrm{C}+\mathrm{D}+\mathrm{E})$ bulunmaktadır. Cinuçen Tanrıkorur tarafindan esere eklenen lafzi terennüm kısmı (A) bulunmaktadır. Bu bölüm ayrıca nakarat olarak kullanılmaktadır.

\section{$\underline{\text { Bölüm Yapılart }}$}

Eser toplam 6 bölümden oluşmaktadır. Eserin I. bölümü Cinuçen Tanrıkorur tarafından esere eklenen lafzi terennüm kısmıdır. Bu bölüm ayrıca nakarat olarak kullanılmaktadır.

Eserin 2. bölümü zemin kısmıdır. İçerisinde 2 ölçü teslim bölümü bulunmaktadır. Ardından I. bölüme dönüş işareti ile dönülmektedir.

Eserin III. bölümü 1. meyan kısmıdır. İçerisinde 2 ölçü teslim bölümü bulunmaktadır. Ardından I. bölüme dönüş işareti ile dönülmektedir.

Eserin IV. bölümü 2. meyan kısmıdır. İçerisinde 2 ölçü teslim bölümü bulunmaktadır. Ardından I. bölüme dönüş işareti ile dönülmektedir.

Eserin V. bölümü 3. meyan kısmıdır. İçerisinde 2 ölçü teslim bölümü bulunmaktadır. Ardından I. bölüme dönüș işareti ile dönülmektedir.

Eserin VI. bölümü 4. meyan kısmıdır. İçerisinde 2 ölçü teslim bölümü bulunmaktadır. Ardından I. bölüme dönüş işareti ile dönülmekte ve karar vermektedir.

\subsubsection{Hicâz İlâhî’ye ait Eser Kurgusu}

Hicâz Illâhî’ye ait eser kurgusu aşağıdaki tabloda gösterilmiştir.

Turkish Academic Research Review - Türk Akademik Araştırmalar Dergisi https://dergipark.org.tr/tr/pub/tarr 


\section{Eser Kurgusu}

\begin{tabular}{|c|c|}
\hline I $\quad\left(\begin{array}{c}2 / 4 u-40 ̈ \\
\mathrm{~A}\end{array}\right)$ & Nakarat Bölümü / Hicâz makāmı dizisi \\
\hline 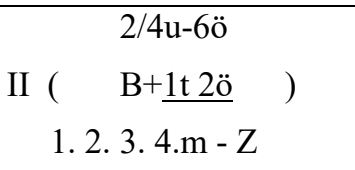 & $\begin{array}{l}\text { Zemin Bölümü / Hicaz Dörtlüsü + Nevâ'da Buselik Beşlisi Hicaz } \\
\text { makāmı dizisi }\end{array}$ \\
\hline $\mathrm{I} \quad\left(\begin{array}{c}2 / 4 \mathrm{u}-40 \ddot{ } \\
\mathrm{A} \\
\mathrm{N}\end{array}\right)$ & Nakarat Bölümü / Hicâz makāmı dizisi \\
\hline 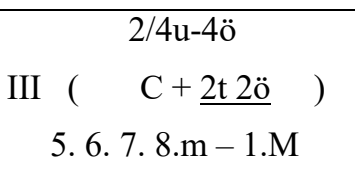 & $\begin{array}{l}\text { 1. Meyan Bölümü / Isfahan Geçkisi + Nevâ'da Buselik Beşlisi } \\
\text { (Hicaz Hümayun Geçkisi) + Dügâh'ta Hicaz Dörtlüsü }\end{array}$ \\
\hline $\left.\begin{array}{c}2 / 4 \mathrm{u}-4 \ddot{0} \\
\mathrm{~A}\end{array}\right)$ & Nakarat Bölümü / Hicâz makāmı dizisi \\
\hline 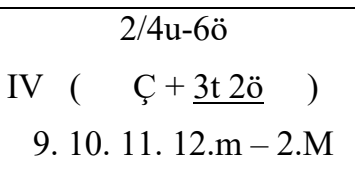 & $\begin{array}{l}\text { 2. Meyân Bölümü / Hüseynî’de Uşşak Dörtlüsü (Hicaz Uzzal } \\
\text { Geçkisi) + Dügâh’ta Hicaz Dörtlüsü }\end{array}$ \\
\hline $\left.\begin{array}{c}2 / 4 \mathrm{u}-4 \ddot{0} \\
\mathrm{~A}\end{array}\right)$ & Nakarat Bölümü / Hicâz makāmı dizisi \\
\hline 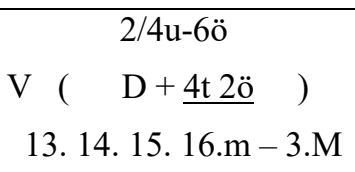 & $\begin{array}{l}\text { 3. Meyân Bölümü / Dügâh’ta Saba Dörtlüsü + Çargâh’ta Hicaz } \\
\text { Dörtlüsü + Dügâh’ta Segâh Çeşnisi (Dügâh makamı geçkisi) }\end{array}$ \\
\hline $\left.\begin{array}{c}2 / 4 \mathrm{u}-4 \ddot{\mathrm{O}} \\
\mathrm{I}\end{array}\right)$ & Nakarat Bölümü / Hicâz makāmı dizisi \\
\hline 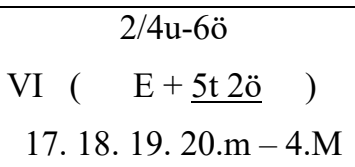 & $\begin{array}{l}\text { 4. Meyân Bölümü / Gülizar Geçkisi + Nevâ'da Buselik Beşlisi + } \\
\text { Dügâh'ta Hicaz Dörtlüsü }\end{array}$ \\
\hline
\end{tabular}




\subsubsection{Hicâz İlâhî’ye ait İcrâ Akışı}

Hicâz İlâhî’ye ait icrâ akışı aşağıdaki tabloda gösterilmiştir.

\section{$\underline{\text { İcrâ Akısı }}$}

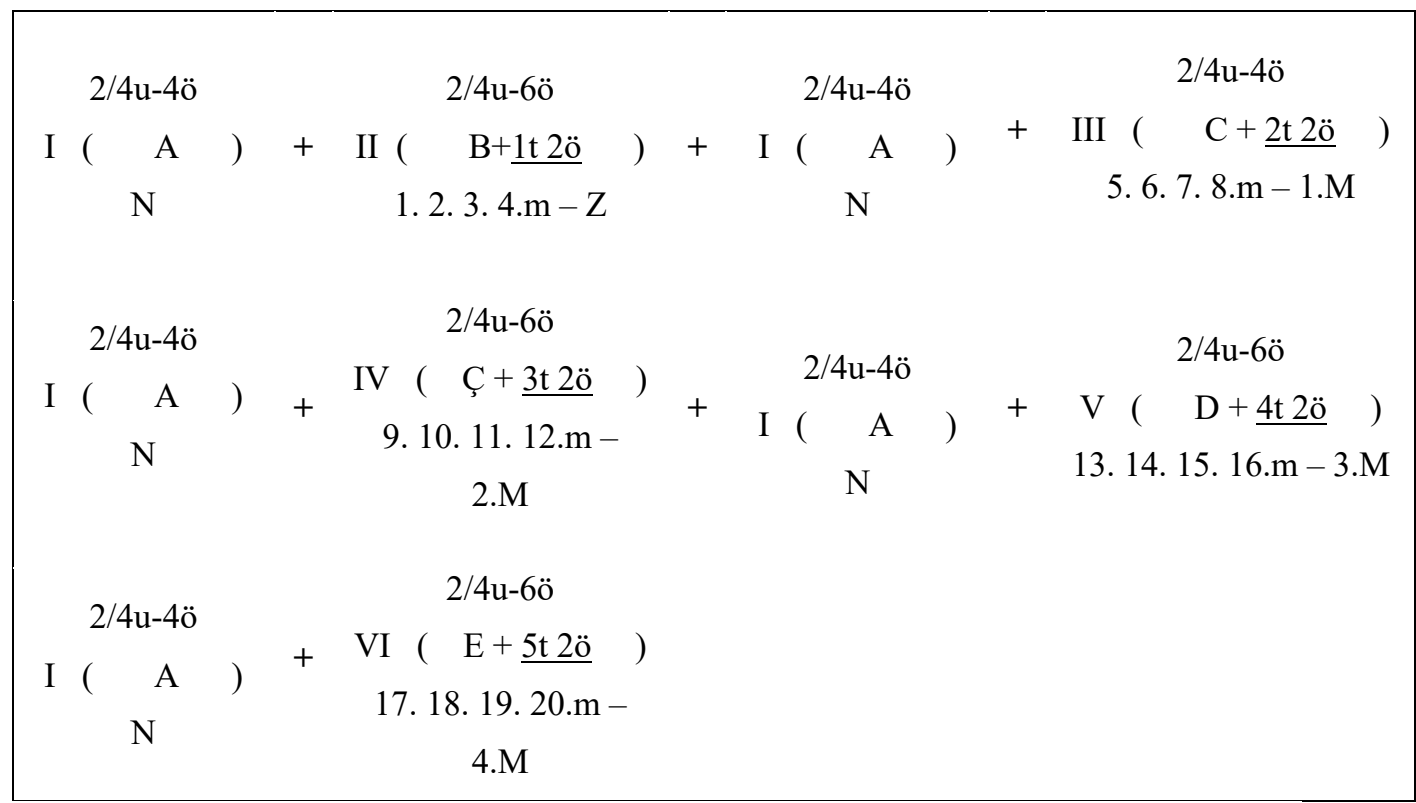

YAKA GELDI, YAKA GIDER
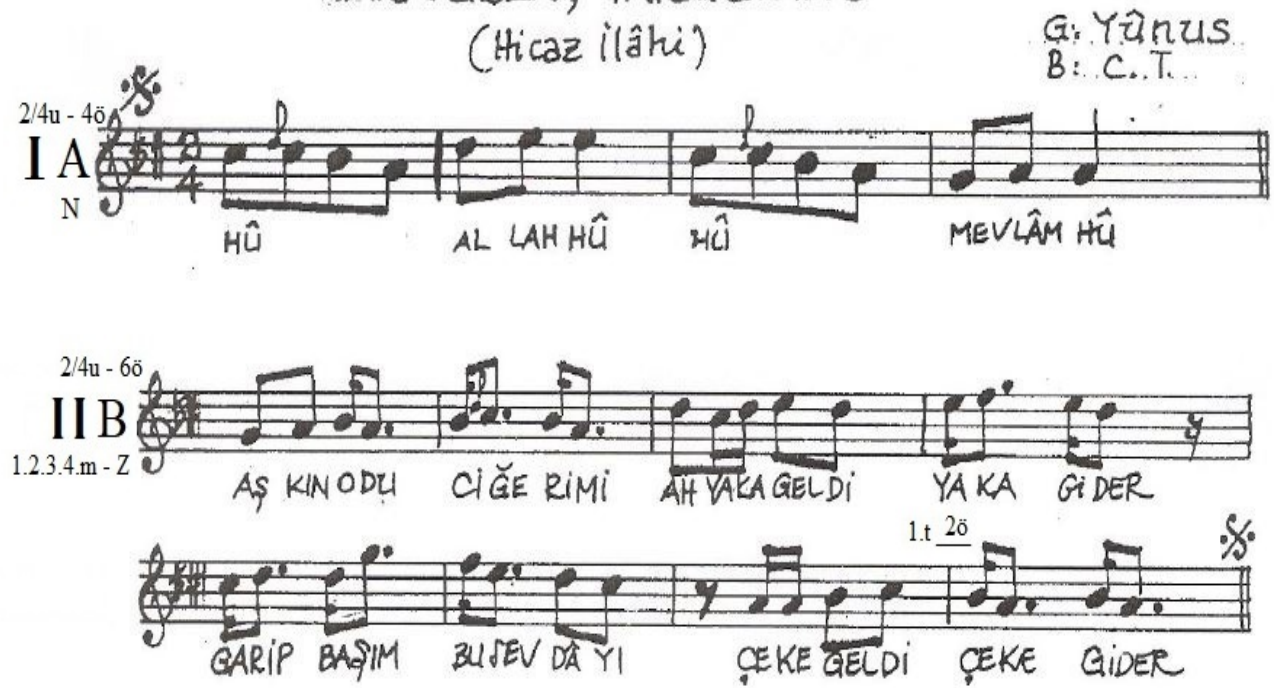

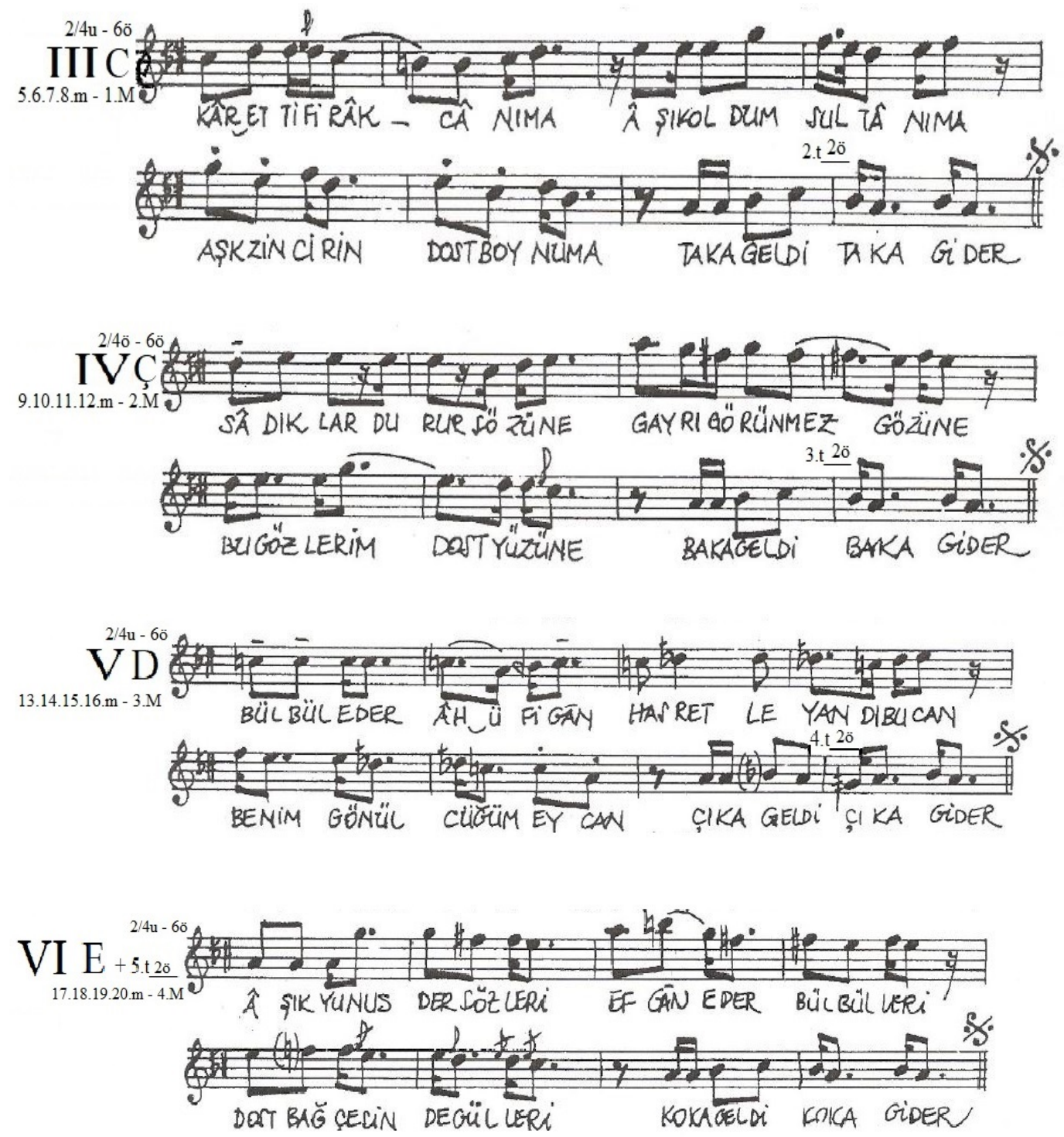

Așkın odu ciğerimi

Yaka geldi yaka gider

Garip başım bu sevdâyı

Çeke geldi çeke gider

Kâr etti firâk cânımâ

Asşı oldum sultanıma

Aşk zincirin dost boynuma

Taka geldi taka gider

Sâdıklar durur sözüne

Gayrl görünmez gözüne

Bu gözlerim dost yüzüne

Baka geldi baka gider 
Bülbül eder âh ü figân

Hasret ile yand bu can

Benim gönülcü̆ü̈m ey can

Çıka geldi çıka gider

Asşık Yûnus der sözleri

Efgân eder bülbülleri

Dost bağçesinde gülleri

Koka geldi koka gider

\section{4- Sonuç ve Öneriler}

Cinuçen Tanrikorur'un Türk Din Musikisi ilâhi formunda bestelemiş olduğu ve çalışmanın örneklemini teşkil eden 5 adet ilâhî de, geçmişten gelen büyük kültür mirasını kendine has özgün bir uslûb ile harmanladığı görülmüştür.

Cinuçen Tanrıkorur ilâhîlerinde güfteye "lafızlar" ve "nakaratlar" eklemiştir. Bu lafizlar, kimi zaman nakarat ile birlikte icra edilirken, kimiz zaman ise direkt nakarat olarak kullanılmıştır. Ayrıca formun yapısından farklı olarak eklenen meyan kısımları eklediği görülmektedir.

Acem Bayram Niyâzında ilâhî'nin güftesine "lafızlar" (Yâ Hû şeklinde) eklemiştir. $\mathrm{Bu}$ lafizlar eser içinde toplam 10 kere tekrarlanmaktadır. Eser $\mathrm{A}+\mathrm{B}+\mathrm{C}+\mathrm{B}^{1}$ şeklinde bir beste biçim yapısına sahiptir. Eserde toplam 3 bölüm, 8 cümle bulunmaktadır. Eserde etkin perdeler incelendiğinde Nevâ perdesinin çokça kullanıldığı görülmüştür.

Bayâtî Tevşih'te ise şarkı formu yapısına benzeyen, ilâhî formunun $A+B$, $\mathrm{A}+\mathrm{B}+\mathrm{C}+\mathrm{B}$ biçim yapısından farklı olarak nakarat kısmından meyan kısmına geçmeden evvel terennüm kısmı eklenmiştir ve beste formuna benzeyen türde eser yapısı görülmektedir. Dolayısıyla $\mathrm{A}+\mathrm{B}+$ Terennüm $+\mathrm{C}+\mathrm{B}$ şeklinde farklı bir beste biçim yapısı oluşmuştur. Eserde toplam 4 bölüm, 14 cümle bulunmaktadır. Eserin etkin perdeleri içinde Çargâh ve Nevâ perdesinin merkez olduğu ve bu perdelerde kalışlar ve müzik cümleleri yaptığı gözlemlenmiştir.

Dügâh İlâhî'de eserin son kısmında Cinuçen Tanrıkorur tarafından güfteye eklenen, "cumhur" olarak icra edilen bölüm bulunmaktadır. Eser, ilahi formunun A + B + Terennüm şeklinde beste biçim yapısına sahiptir. Eserde toplam 2 bölüm, 6 cümle bulunmaktadır. Eserdeki etkin perdelerin Dügâh ve Çargâh olduğu ve bu perdelerinde ezgi merkezi olduğu görülmüştür.

Turkish Academic Research Review - Türk Akademik Araştırmalar Dergisi https://dergipark.org.tr/tr/pub/tarr 
Gülizâr İlâhî'de eserin güftelerindeki yapıya uygun olarak tartım yapılarında değişiklikler bulunmaktadır. Eserin nakarat ve ayrıca karar olarak kullanılan kısmı Cinuçen Tanrıkorur tarafından güfteye eklenmiştir. Eser, ilahi formunun $\mathrm{A}+\mathrm{B}$ (Zemin + Nakarat) şeklindeki beste biçim yapısına benzemekte olup, bunun çeşitli varyasyonların eklenmiş hali olarak çeşitlendiği gözlemlenmiştir. Eserde toplam 2 bölüm, 10 cümle bulunmaktadır. Eserdeki etkin perdelerden Çargâh perdesinin Ezgi merkezinde bulunması ve Hüseyni perdesinin de hem geçki hem de bir diğer ezgi merkezinde olan perde olduğu görülmüştür.

Hicâz İlâhî’'de A + B + C + B + $\mathrm{C}^{1}+\mathrm{B}+\mathrm{C}^{2}+\mathrm{B}+\mathrm{C}^{3}+\mathrm{B}$ şeklinde birden çok meyan kısmının bulunduğu gözlenmiştir. $\mathrm{Bu}$ bestesinde makam yapısına sadık kalarak, meyanlarda farklı makamlara geçişler yapılmış, ilâhî makam yönüyle zenginleştirilmiştir. Eserin giriş kısmında ve dönüşlerde icra edilen nakarat kısmı Cinuçen Tarınkorur tarafindan ilâhî’ye eklenmiştir. Eserde toplam 6 bölüm, 6 cümle ve 6 kez tekrar edilen nakarat bölümü bulunmaktadır. Eserdeki etkin perdelerden olan Nim hicaz ve Hüseyni perdesinin makamın güçlüsü olan Nevâ perdesinden daha ziyadesiyle kullanıldığı ve Ezgi merkezinde olan perdeler olduğu anlaşılmıştır.

Cinuçen Tanrıkorur'un ilâhî formundaki bestecilik anlayışının diğer ilâhî formundaki bestecilerin bestelemiş olduğu ilâhîlerden farklı ve yenilikçi olduğu, ayrıca formun nazari bakımdan karar perdesi ve güçlü perdesinin yanı sıra diğer perdelerin de hem ezgi merkezinde hem de geçki olarak kullanmasının makamın yapısını kuvvetlendirdiği gibi, makam anlatımında da örnek teşkil edilebileceği, ilâhî formu form yapısı ve besteciliğinde yeni ve faydalı bir fikir oluşturduğu görülmektedir.

\section{Kaynakça}

Akdoğu, O. (1996). Türk Müziğinde Türler ve Biçimler. İzmir: Ege Üniversitesi Basimevi.

Alvan, T., \& Alvan, H. (2016). Saz ve Söz Meclisi "Şiir ve Musık̂̀ Medeniyetimiz". İstanbul: Şule Yayınları.

Ayverdi, İ. (2010). Misalli Büyük Türkçe Sözlük. İstanbul: Kubbealtı, Bilnet Matbaacilı.

Belviranl, Ö. F. (2016, 09 01). Tarihî, kültürel, icrâî, nazarî ve biçimsel yönleriyle Türk Din Mûsikîsinde ilâhî formu nasıldır? (Ç. Toptaş, Röportaj Yapan)

Demirtaş, Y. (2009). Türk Din Mûsikîsi Formları. Firat Üniversitesi Illâhîyat Fakültesi Dergisi, 213-227. 
Devellioğlu, F. (2013). Osmanlıca - Türkçe Ansiklopedik Lûgat. Ankara: Aydın Kitabevi.

Güngör, H. (2001). Cinuçen Tanrıkorur'un Besteciliği Üzerine. Musikişinas, 122127.

Kaçar, G. Y. (2012). Türk Mûsikîsi Rehberi. Ankara: Maya Akademi.

Kaçar, G. Y. (2020). Türk Mûsikîsinde Eser ve İcrâ Tahlîli Yöntemleri. Ankara: Gece Kitaplığı.

Kaçar, G. Y., \& Aydın, A. (2020). Avşar Bozlağı'na Yapılan Dört Farklı “Açış” İcrâ Örneğinin Motif Tabanlı Biçim Tahlîli. İtobiad, 1779.

Özalp, N. (1992). Türk Mûsikîsi Beste Formları. Ankara: TRT Müzik Dairesi Başkanlığı.

Özcan, N. (2011). Tekke Mûsikisi: DİA İslâm Ansiklopedisi. https://islamansiklopedisi.org.tr/: $\quad$ https://islamansiklopedisi.org.tr/tekkemusikisi adresinden alınmıştır

Öztuna, Y. (1969). Türk Mûsikîsi Ansiklopedisi I. Cilt. İstanbul: Milli Eğitim Basımevi.

Uludağ, S. (2012). Tasavvuf Terimleri Sözlüğ̈̈. İstanbul: Kabalcı Yayınevi.

Uzun, M. (2000). Ilâhi: TDV İslam Ansiklopedisi. TDV İslâm Ansiklopedisi Web Sitesi: https://islamansiklopedisi.org.tr/ilahi adresinden alınmıştır

Turkish Academic Research Review - Türk Akademik Araştırmalar Dergisi https://dergipark.org.tr/tr/pub/tarr 